\title{
Tectonics
}

\author{
RESEARCH ARTICLE \\ 10.1029/2019TC006043 \\ Key Points: \\ - Structural, borehole, and seismicity \\ data from the Western Afar Margin \\ serve to study continental breakup \\ processes and rotational rifting \\ - Antithetic faults bounding marginal \\ grabens are currently \\ accommodating significant \\ deformation along the margin \\ - Current extension is due to rotation \\ of the Danakil Block; a previous \\ oblique extension phase was likely \\ related to Arabian plate motion
}

\author{
Correspondence to: \\ F. Zwaan, \\ frank.zwaan@geo.unibe.ch
}

Citation:

Zwaan, F., Corti, G., Sani, F., Keir, D., Muluneh, A. A., Illsley-Kemp, F., \& Papini, M. (2020). Structural analysis of the Western Afar Margin, East Africa: Evidence for multiphase rotational rifting. Tectonics, 39, e2019TC006043. https://doi.org/10.1029/2019TC006043

Received 23 DEC 2019 Accepted 10 APR 2020 Accepted article online 9 MAY 2020

\section{Structural Analysis of the Western Afar Margin, East Africa: Evidence for Multiphase Rotational Rifting}

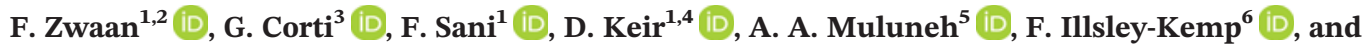 \\ M. Papini ${ }^{1}$
}

${ }^{1}$ Dipartimento di Scienze della Terra, Università degli Studi di Firenze, Florence, Italy, ${ }^{2}$ Current affiliation: Institut für Geologie, Universität Bern, Bern, Switzerland, ${ }^{3}$ Consiglio Nazionale delle Ricerche, Istituto di Geoscienze e Georisorse, Florence, Italy, ${ }^{4}$ School of Ocean and Earth Science, University of Southampton, Southampton, UK, ${ }^{5}$ School of Earth Sciences, Addis Ababa University, Addis Ababa, Ethiopia, ${ }^{6}$ School of Geography, Environment and Earth Sciences, Victoria University of Wellington, Wellington, New Zealand
Abstract The Afar region in East Africa represents a key location to study continental breakup. We present an integrated structural analysis of the Western Afar Margin (WAM) aiming to better understand rifted margin development and the role of plate rotation during rifting. New structural information from remote sensing, fieldwork, and earthquake data sets reveals that the N-S striking WAM is still actively deforming and is characterized by NNW-SSE normal faulting as well as a series of marginal grabens. Seismicity distribution analysis and the first-ever borehole-calibrated sections of this developing passive margin show recent slip concentrated along antithetic faults. Tectonic stress parameters derived from earthquake focal mechanisms reveal different extension directions along the WAM $\left(82^{\circ} \mathrm{N}\right)$, in $\operatorname{Afar}\left(66^{\circ} \mathrm{N}\right)$ and in the Main Ethiopian Rift $\left(108^{\circ} \mathrm{N}\right)$. Fault slip analysis along the WAM yields the same extension direction. Combined with GPS data, this shows that current tectonics in Afar is dominated by the local rotation of the Danakil Block, considered to have occurred since $11 \mathrm{Ma}$. Earlier stages of Afar development (since 31-25 Ma) were most likely related to the large-scale rotation of the Arabian plate. Various authors have proposed scenarios for the evolution of the WAM. Any complete model should consider, among other factors, the multiphase tectonic history and antithetic fault activity of the margin. The findings of this study are not only relevant for a better understanding of the WAM but also provide insights into the role of multiphase rotational extension during rifting and passive margin formation in general.

Plain Language Summary The Earth's continents are in gradual but perpetual motion, driven by large plate tectonic forces in the Earth's deep interior. A crucial process is the stretching and breaking up of continents, initially forming localized rift or graben depressions, followed by the opening of a new ocean flanked by the margins of the newly divided continents (passive margins). Rifts and passive margins are important because of their vast resource potential (e.g., oil, gas, geothermal energy), but pose also severe risks (volcanism, earthquakes, and landslides) since they are often home to large populations.

We focus on the Western Afar Margin in Ethiopia, where the African continent is currently splitting apart, providing a unique research opportunity. In the framework of an international collaborative effort, we combined satellite imagery, topography data, field observations, GPS, and earthquake measurements in order to map out the present-day geology and tectonic activity along the margin.

Our results show the complexity of tectonic plate movements: We find evidence for two phases of continental stretching in Ethiopia that both involve the rotation of tectonic plates. We also observe active faulting, which may help to assess seismic risks in the area. Our study helps to better understand passive margins worldwide.

\section{Introduction}

\subsection{Rifting and Rotational Extension}

Extension of the lithosphere, leading to rifting and breakup of continents is an integral part of the global plate tectonic system, and a thorough understanding of the processes involved is of great interest for scientific, economic, and societal reasons. Rifts and passive margins hold extensive sedimentary archives containing crucial information regarding global change, as well as vast resource potential (e.g., oil, gas, geothermal energy), but pose also severe risks in the shape of volcanism, earthquakes, and (submarine) landslides,
(C)2020. American Geophysical Union. All Rights Reserved. 
(a)

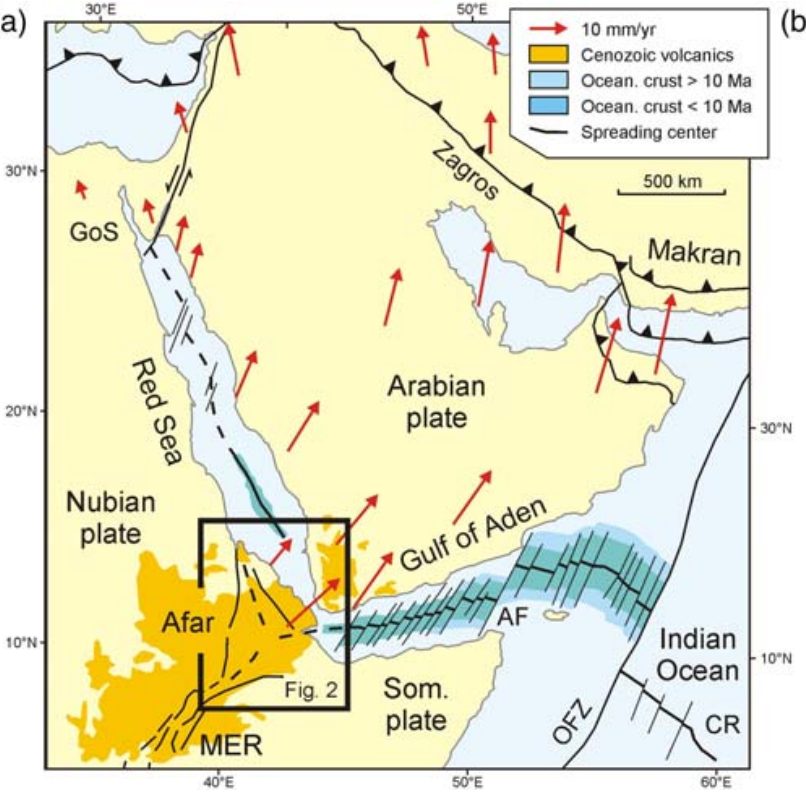

(b)

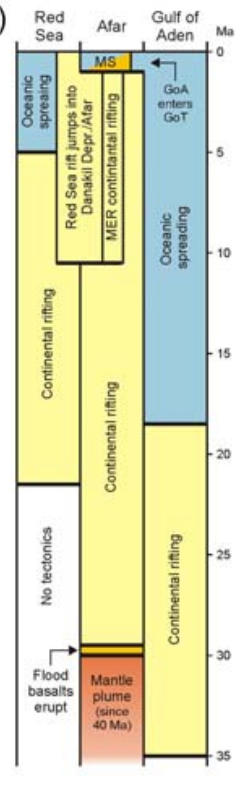

Figure 1. (a) Tectonic setting of Red Sea-Afar-Gulf of Aden rift system (modified after Bosworth, 2015). Note the westward decreasing width of the oceanic crust as a result of the rotation of the Arabian plate. AF: Alula-Fartaq fracture zone, CR: Carlsberg Ridge, GoS: Gulf of Suez, OFZ: Owen Fracture Zone. Red arrows represent GPS velocities from ArRajehi et al. (2010) and indicate counterclockwise rotation of the Arabian plate. (b) Timeline of main tectonic events in the Red Sea-Afar-Gulf of Aden rift system (see text for details). GoA: Gulf of Aden, MER: Main Ethiopian Rift, MS: Magmatic segments. Modified after Zwaan, Corti, Keir, \& Sani (2020).

especially since these areas of the world are often home to large populations (e.g., Brune, 2016; Catuneanu et al., 2009; Davison \& Underhill, 2012; Haq et al., 1987; Kirschner et al., 2010; Levell et al., 2011; Zou et al., 2015). However, a common challenge to researchers is that once breakup occurs and passive margins are formed, the remnants of the once active continental rift are often situated offshore and mostly covered by thick (postrift) sedimentary sequences (e.g., Argent et al., 2000; Straume et al., 2019). Hence, the Afar region in East Africa represents a unique opportunity to study extensional processes and associated structures (e.g., fault geometries and kinematics); it contains active rifts in various stages of maturity, from initial continental rifting to continental breakup, oceanic spreading, and passive margin formation, all accessible onshore (e.g., Illsley-Kemp, Bull, et al., 2018; Varet, 2018; Figure 1).

The Afar region is of further interest due to the occurrence of rotational rifting related to the anticlockwise pivoting of the Arabian plate (e.g., ArRajehi et al., 2010; Bellahsen et al., 2003; Smith, 1993, Figure 1). A common simplification is, namely, that rifting involves constant along-strike extension conditions (e.g., Vink, 1982). Yet in natural rifts, deformation rates often change along-axis due to plate rotation about an Euler pole (e.g., Martin, 1984; Muluneh et al., 2013; van der Pluijm \& Marshak, 2004; Zwaan, Schreurs, \& Rosenau, 2020). Recent analogue and numerical modeling studies show that such rotational plate motion strongly affects the development and allows propagation of rifting and continental breakup on regional to global scales (e.g., Molnar et al., 2017, 2018; Mondy et al., 2018; Zwaan, Schreurs, \& Rosenau, 2020). The development of the Gulf of Aden and Red Sea rifts is a prime example, where extension rates double over every 1,000 km (ArRajehi et al., 2010, Figure 1, see section 1.2). The Afar region thus provides a unique natural laboratory to study the effects of rotational tectonics on rifting and passive margin development.

\subsection{Geology of Afar}

Afar forms a triangular depression near and partially below sea level, between the Ethiopian and Somalian Plateaux to the west and south and the Danakil and Ashia Blocks to the NE and east (Figures 1 and 2). It is an area of highly extended crust, 25 to $15 \mathrm{~km}$ thick from south to north, compared to the $40 \mathrm{~km}$ thick crust below the Ethiopian Plateau (Hammond et al., 2011; Makris \& Ginzburg, 1987). From the north, the Red 

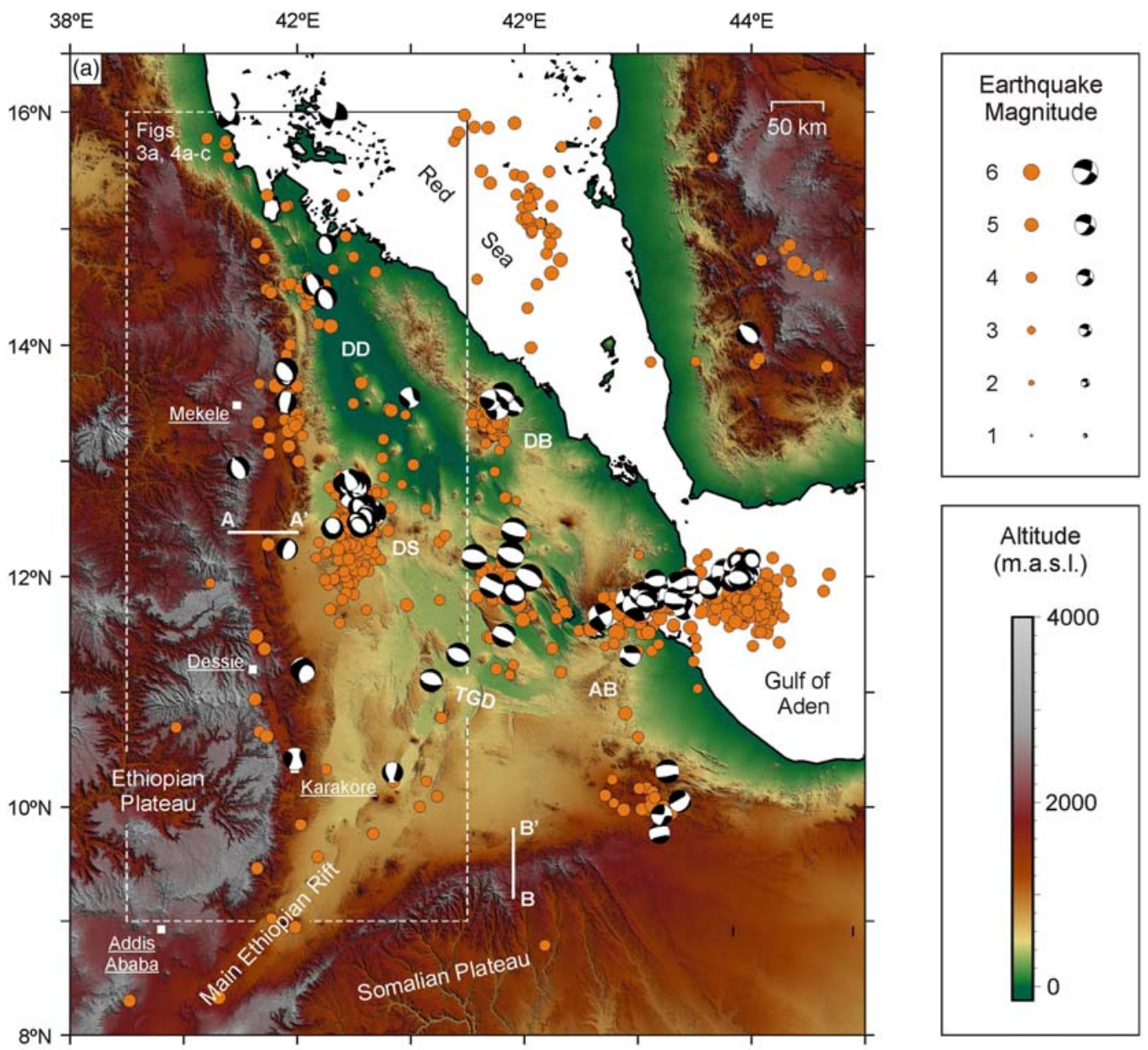

Altitude

(m.a.s.l.)

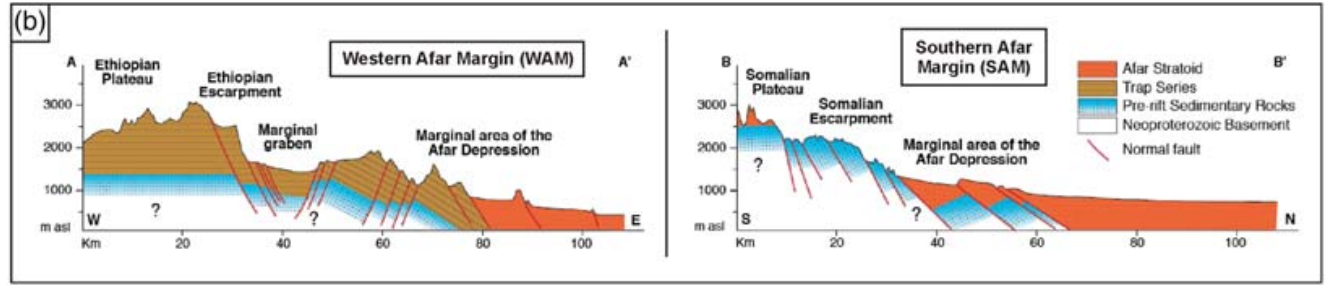

Figure 2. (a) Afar Depression in East Africa and the location of the Western Afar Margin (WAM). Red dots indicate historic earthquakes from the 1970-2018 NEIC earthquake catalog. Focal mechanisms are derived from the CMT catalog. AB: Aisha Block, DB: Danakil Block. DD: Danakil Depression, DS: Dabbahu segment, TGD: Tendaho-Goba'ad Discontinuity. Topography is derived from ASTER data (90 m resolution). (b) Sections A-A' and B-B', illustrating the difference in structural style between (A- $\left.\mathrm{A}^{\prime}\right)$ the Western Afar Margin (WAM) and (B-B') the Southern Afar Margin (SAM). The former is dominated by antithetic faulting (towards the plateau) and associated marginal grabens, whereas the latter is characterized by synthetic (basinward) faulting. Section locations are indicated in (a). Image modified after Corti et al. (2015) and Beyene and Abdelsalam (2005).

Sea rift axis steps into the Danakil Depression at the Gulf of Zula and extends to the SE through a number of offset rift basins. The Gulf of Aden rift axis enters Afar from the east at the Gulf of Tadjura (e.g., Makris \& Ginzburg, 1987; Manighetti et al., 1998, 2001). To the south and separated from the Red Sea and Gulf of Aden system by the Tendaho-Goba'ad Discontinuity (TGD), the Ethiopian Rift forms the third branch of the current Afar triple junction (Wolfenden et al., 2004). 
The formation of the Afar Depression is associated with two large-scale processes: the rotation of the Arabian plate with respect to the Nubian/African plate and the emplacement of a thermal mantle anomaly beneath the continental lithosphere (Figure 1b). Prior to rifting (around 40-30 Ma) a mantle plume is thought to have impacted the lithosphere below Afar (e.g., Rooney, 2017 and references therein). In Afar, this caused an intense flood basalt event at $30 \mathrm{Ma}$ (Hoffmann et al., 1997), the remains of which (Trap series) are found in large parts of Ethiopia and Yemen (e.g., Bosworth et al., 2005; Mohr, 1983a, Figure 1a). The outpouring of most of these basalt flows took place within a ca. 1 Myr period and covered the preceding Oligocene laterite surface with up to $2 \mathrm{~km}$ of volcanics (Abbate et al., 2015; Hoffmann et al., 1997; Mohr, 1983a). Meanwhile, rifting started in the eastern parts of the Gulf of Aden at ca. 35 Ma (Leroy et al., 2010; Purcell, 2017 and references therein) related to the counterclockwise motion of the Arabian plate about a rotation pole currently positioned near $31.7^{\circ} \mathrm{N}, 24.6^{\circ} \mathrm{E}$ (ArRajehi et al., 2010; Bellahsen et al., 2003; McKenzie et al., 1970). Ongoing divergence of the Arabian plate caused rift propagation towards Afar around 26-31 Ma (Ayalew et al., 2006; Wolfenden et al., 2005) and subsequently to the Red Sea at ca. $23 \mathrm{Ma}$ (Szymanski et al., 2016), creating a continuous L-shaped rift zone bordering the southern edges of the Arabian plate (Bosworth, 2015; Bosworth et al., 2005). Oceanic spreading in the easternmost Gulf of Aden was established around 17.6 Ma or even $20 \mathrm{Ma}$ (D'Acremont et al., 2006; d'Acremont et al., 2010; Fournier et al., 2010; Leroy et al., 2010; Manighetti et al., 1997) and reached the western Gulf of Aden around $10 \mathrm{Ma}$ (Figure 1a), whereas oceanization in the Red Sea started around 5 Ma (e.g., Augustin et al., 2014; Bosworth et al., 2005; Cochran, 2005) or possibly as early as $12 \mathrm{Ma}$ (Izzeldin, 1987). Afar has however not reached complete breakup so far, reflecting a more complex local geological history (Figure 1).

The formation of the Southern Afar Margin (SAM) probably started at ca. 24 Ma (Bosworth et al., 2005, Figure 2). Along the Western Afar Margin (WAM), rift-related volcanism and geomorphology indicates that extension simultaneously initiated in the north between 26 and $31 \mathrm{Ma}$ and migrated to the south until $11 \mathrm{Ma}$ (Ayalew et al., 2006; Tesfaye \& Ghebreab, 2013; Wolfenden et al., 2005; Zanettin \& Justin-Visentin, 1975). Around that time the Danakil Block, a continental sliver that was part of the stretched Red Sea/Afar rift zone (Collet et al., 2000; Morton \& Black, 1975; Redfield et al., 2003; Stab et al., 2016), started a counterclockwise rotation (Eagles et al., 2002; McClusky et al., 2010; Sichler, 1980). This rotational motion is associated with the formation of the Danakil Depression, the current rift axis in northern Afar, which together with the parallel Red Sea trend forms a system of overlapping rift axes (Mohr, 1972, Figures 1a and 2). Simultaneously, the Aisha Block began a clockwise motion (Kidane, 2015), possibly due to the propagating Gulf of Aden rift system. The northern part of the currently still continental Main Ethiopian Rift was formed around $11 \mathrm{Ma}$ (DeMets \& Merkouriev, 2016; Wolfenden et al., 2004) due to the eastward motion of the Somalian plate with respect to the Nubian plate and by linking up with the Red Sea and Gulf of Aden system, thus establishing the present Afar triple junction (Figures 1a and 2).

At around 2 Ma deformation in Afar, which had over time gradually shifted from the rift margins into the depression, became strongly localized along narrow segments in the axial portion of the rift valley floor (e.g., Wolfenden et al., 2005). Here extension is accommodated primarily by episodic diking rather than pure faulting (e.g., Barnie et al., 2015; Hayward \& Ebinger, 1996; Medynski et al., 2016; Wright et al., 2006). These active magmatic segments, referred to as Axial Volcanic Ranges in Afar and Wonji Fault belt along the axis of the MER (e.g., Barberi et al., 1972; Dumont et al., 2019; Mohr, 1967), create significant seismicity (Figure 2a) and are considered to represent embryonic spreading centers heralding imminent breakup (e.g., Ayalew et al., 2019; Barberi et al., 1970; Barberi \& Varet, 1977).

Most recent scientific studies concerning Afar tend to focus on the development and interaction of the axial magmatic segments, as well as the associated continental breakup processes (e.g., Dumont et al., 2019; Pagli et al., 2019). In contrast, the parts of Afar that represent (future) passive margins and thus provide unique research opportunities (i.e., the SAM and WAM, Figure 2) receive relatively little attention, partially due to the often challenging geographical, climatological, and political conditions in Ethiopia and Eritrea (e.g., Fazzini et al., 2015; Varet, 2018; Williams, 2016). The focus of this paper lies on the structural geology of the Western Afar Margin (WAM), and our aim is to provide an up-to-date detailed structural interpretation of the area by bringing together data from previous publications, regional mapping, well logs, earthquake surveys and recent fieldwork, and fitting these data in a regional tectonic framework. 

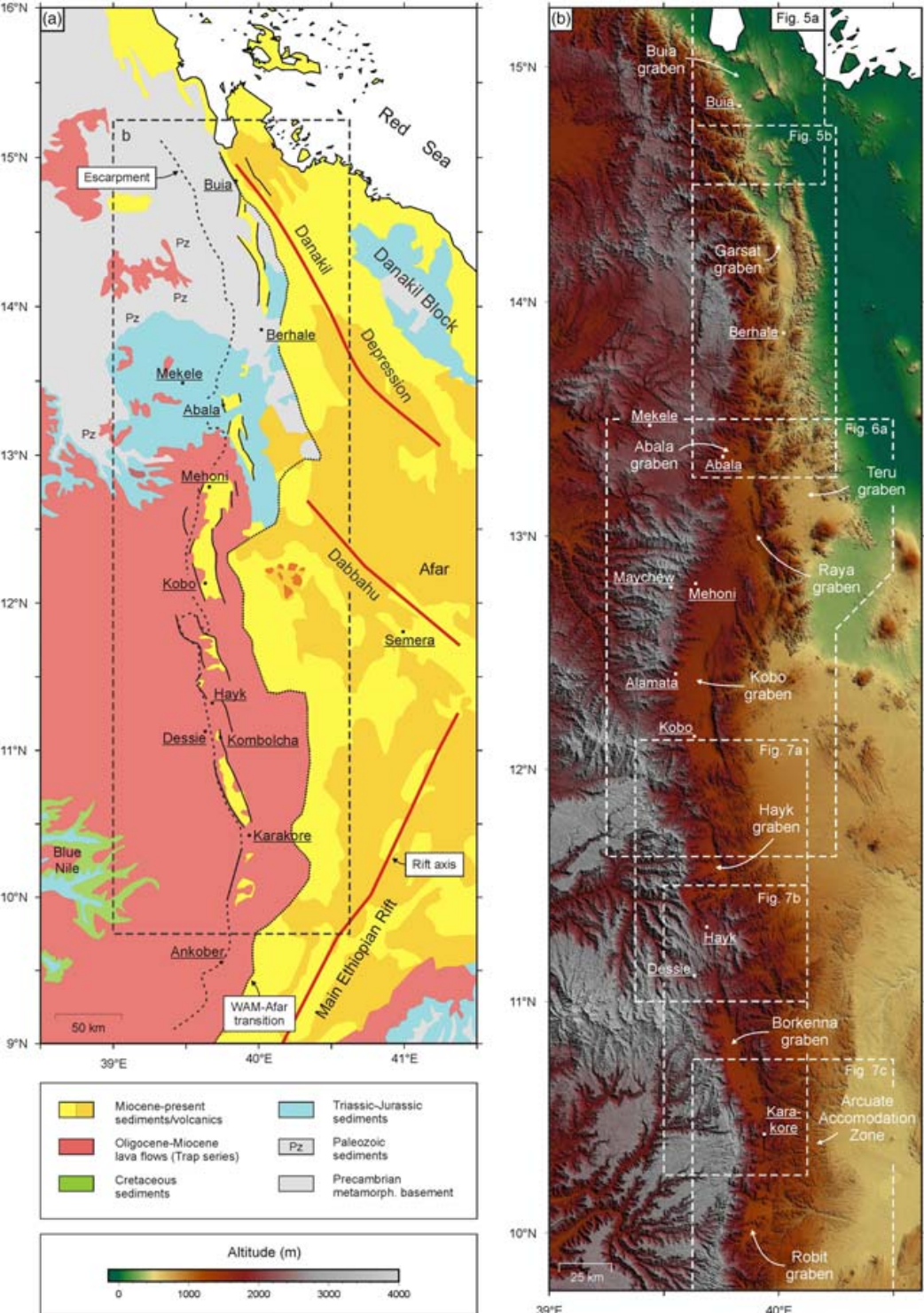

Figure 3. (a) Geological map of the WAM. Modified after Arkin et al., 1971; Kazmin (1972), Barberi et al. (1972) and Kazmin et al. (1978). (b) Distribution of marginal grabens along the Western Afar Margin (WAM). The dotted boxes indicate the locations of detailed maps presented in Figures 5 and 7-9.

\subsection{The Western Afar Margin}

The ca. N-S striking WAM represents a sharp transition in both topography and crustal thickness from the Ethiopian Plateau to Afar over a distance of 50-100 km (Figure 2). Altitudes on the plateau reach as high as $4 \mathrm{~km}$, whereas Afar lies near and even below sea level in the north. Crustal thickness reduces from $40 \mathrm{~km}$ beneath the plateau to $25 \mathrm{~km}$ beneath southern and central Afar and to $15 \mathrm{~km}$ beneath the Danakil Depression (Hammond et al., 2011).

The lithology of the WAM can be divided in six main units, separated by planation surfaces that reflect the geological history of the Afar region (Abbate et al., 2015; Coltorti et al., 2007, 2015, Figure 3a). The oldest rocks are found in the north and belong to the Precambrian (Neoproterozoic) metamorphic basement, containing a structural grain inherited from the Panafrican orogeny (e.g., Collet et al., 2000; Drury et al., 1994; Ghebreab \& Talbot, 2000). Near the city of Mekele, modest occurrences of Paleozoic sandstones and 
glacial deposits occur (Arkin et al., 1971). The next unit consists of Triassic Adigrat sandstones and Jurassic limestones that are abundant in the Mekele basin (Alemu et al., 2018; Arkin et al., 1971; Beyth, 1972). Cretaceous deposits are only outcropping in the SW where the Blue Nile cuts deep into the Ethiopian Highlands (Gani et al., 2007; Kazmin, 1972). At about $13^{\circ} \mathrm{N}$, a distinct lithological divide occurs between the north, where Precambrian-Jurassic units crop out, and the south, where Oligocene-Miocene Trap basalts predominantly cover the Ethiopian Plateau and WAM. Patches of these lava flows are also present in the north, suggesting that their preerosion extent was significantly larger (e.g., Mohr, 1983a; Mohr \& Zanettin, 1988). Extensive Miocene-present sedimentary and volcanic infill (among which the Pliocene-Quaternary Stratoid units, Barberi \& Santacroce, 1980) forms the most-recent unit and covers the Afar floor, but has also accumulated in depressions along the WAM and on the Ethiopian Plateau (Figure 3a).

The structural style of the WAM is characterized by a number of notable features. Firstly, faulting along the margin is generally considered to be dominantly antithetic (i.e. dipping away from the Afar rift basin; e.g., Abbate \& Sagri, 1969; Baker et al., 1972; Mohr, 1983b; Stab et al., 2016; Wolfenden et al., 2005, Figure 2b). As a result, fault blocks seem to be increasingly tilted towards Afar as indicated by increasing dips of the Trap basalt layers and rotated dikes, in a system which has been described as "flexure" of the crust into Afar (Abbate \& Sagri, 1969). Furthermore, a series of faulted basins, referred to as "marginal grabens," (Mohr, 1962) align along the WAM (Figures 2 and 3). These grabens, (partially) filled with Pliocene-Recent sediments (Abbate et al., 2015; Chorowicz et al., 1999), are associated with the dominant antithetic style faulting, a situation that is in contrast to the SAM and Yemen margin, of which the bordering plateaus have very similar altitudes, but faults are considered to be dominantly synthetic (i.e., dipping basinward, Baker et al., 1972; Berhe, 1985, 1986; Beyene \& Abdelsalam, 2005, Figure 2b). Where antithetic faulting occurs along the SAM or Yemen, no marginal grabens have developed (Berhe, 1985, 1986; Davison et al., 1994, 1998; Geoffroy et al., 1998; Tesfaye et al., 2003). Terminology and toponymy in the area are often confusing since authors regularly use different names and spelling, due to changing political realities and the difficulties in translating local names in Latin script (Gouin, 1979; Williams, 2016). In this work, we follow and refine the marginal graben nomenclature established by Zwaan, Corti, Keir, \& Sani (2020) (Figure 3b, see also the supplementary material: Zwaan, Corti, Sani, et al., 2020).

Another important feature is the presence of ongoing seismic activity along the WAM. Most earthquakes in the region are concentrated along the rift axes of the Red Sea, Gulf of Aden, central Afar and the MER (e.g., Illsley-Kemp et al., 2017; Illsley-Kemp, Bull, et al., 2018; Illsley-Kemp, Keir, et al., 2018; Tesfaye \& Ghebreab, 2013, Figure 2a). Some minor activity is registered at the SAM as well, but a significant proportion of the region's seismicity is recorded along the whole of the WAM (e.g., Ayele et al., 2007; Craig et al., 2011; Goitom et al., 2017; Gouin, 1970, 1979; Hofstetter \& Beyth, 2003; Illsley-Kemp, Keir, et al., 2018, Figure 2a). Historical accounts describe devastating earthquakes along the margin and as recent as 1961 a series of earthquakes with magnitudes up to 6.4 struck Korakore, causing significant damage in the area (Gouin, 1979, Figure 2a). The ongoing activity shows that WAM is not a true passive margin yet (Corti et al., 2015; Zwaan, Corti, Keir, \& Sani, 2020).

\section{Methods}

We use three different approaches in order to obtain new data for an integrated structural interpretation of the WAM and adjacent parts of Afar, involving (1) analysis of earthquake data sets to quantify current deformation in the region, and to characterize active faults, (2) large-scale structural mapping by means of geomorphological analysis, and (3) new field data as well as unique well logs collected at key locations in the study area to verify and refine the structural interpretation. These methods are described in more detail below, and extensive supplementary material is publicly available in the form of a GFZ Data Publication (Zwaan, Corti, Sani, et al., 2020).

\subsection{Seismicity Analysis}

Earthquake data help to visualize ongoing tectonic activity in the area. We consider data from various sources. Firstly, the National Earthquake Information Centre (NEIC) catalog (849 earthquakes since 1973, https://earthquake.usgs.gov) which is complete above magnitudes of ca. M4, and hypocenter positions have error bars of ca. $+/-20 \mathrm{~km}$. We combine the NEIC catalog with focal mechanism data (99 events from the 
Global Centroid Moment Tensor (CMT) Project catalog; Dziewonski et al., 1981; Ekström et al., 2012, https://www.globalcmt.org), to obtain a coarse impression of the large-scale tectonics in Afar (Figure 2).

For more detailed analysis, we use high-resolution data from the study area. We use the local earthquake catalogs from Ebinger et al. (2008), Keir et al. (2006, 2009), Belachew et al. (2011), and Illsley-Kemp, Keir, et al. (2018) with a total of 13,499 events from the period 2001-2013. These catalogs together provide coverage of large parts of the WAM with a magnitude of completeness of a little above $\mathrm{M}_{\mathrm{L}} 2$ and were used to compute spatial variations in seismic moment release (SMR) of the area. Furthermore, the extraction of T-axes using earthquake focal mechanisms from the NEIC catalog as well as the Keir et al. (2006) and Illsley-Kemp, Bull, et al., (2018), Illsley-Kemp, Keir, et al., (2018) surveys provides an insight of ongoing fault slip style and direction.

In order to better resolve the locus of faulting and subsurface fault geometry of the WAM, we used the earthquake data sets of Belachew et al. (2011) and Illsley-Kemp, Keir, et al. (2018). To homogenize our earthquake data set, we relocated the Belachew et al. (2011) catalog using NonLinLoc and the same velocity model as applied by in Illsley-Kemp, Keir, et al. (2018). From this now standardized and combined data set, we use a selection of 3,689 earthquakes with epicenter location error bars of $+-5 \mathrm{~km}$ or less in three dimensions (xyz) for subsequent structural analysis plotted in both map and section view using Generic Mapping Tools (GMT, http://gmt.soest.hawaii.edu/).

\subsection{Structural Mapping}

Mapping of the structures within the study area was predominantly carried out through geomorphological analysis in QGIS (www.qgis.org). Detailed (30 m resolution) Shuttle Radar Topography Mission (SRTM) and Advanced Spaceborne Thermal Emission and Reflection Radiometer (ASTER) digital topography data from NASA and METI (https://earthexplorer.usgs.gov) provide an excellent basis for structural mapping, especially due to the dry climate preserving fault-related topography in the area (e.g., Chorowicz et al., 1999; Fazzini et al., 2015). Satellite images and the possibility to observe these in 3D in Google Earth Pro allow additional quality control and the identification of other features such as dikes and tectonic lineaments. Criteria for a proper fault interpretation include the presence of layering in the hanging wall, the general shape of tilted fault blocks, and the apparent presence of a fault plane. Especially the pre-rift Trap basalts are of great interest, as they provide a pre-rift subhorizontal reference that allows us to recognize syn-rift deformation.

\subsection{Field and Well Data Collection}

A recent field campaign along the WAM provided a crucial opportunity to ground truth the large-scale structural interpretation acquired through the methods described in sections 2.1 and to gain further insights in the associated tectonic regime. Since fault measurements are available from the northernmost (Buia area, Sani et al., 2017) and the southern sections of the margin (Robit and Borkenna grabens, Chorowicz et al., 1999), we focused our efforts on the central part of the WAM, between Berhale to the north and the Karakore Fault in the south (Figure 3b). We visited various key locations, that is, outcrops along interpreted faults, to collect fault data (fault strike, dip direction, pitch, and sense of fault slip). Additional field data were collected during a second campaign in the northernmost WAM in Eritrea, where N-S trending faults offsetting the Dandiero basin sedimentary infill were measured. Analysis of fault data with Wintensor (Delvaux \& Sperner, 2003) was performed in order to determine fault characteristic and the stress field under which they developed.

Furthermore, the first-order geomorphological observations made along the margin during both field campaigns are highly valuable for assessing fault activity. We also collected unique well logs from irrigation projects near the towns of Mehoni, Alamata, and Kobo in the agriculturally important Kobo graben (Tadesse et al., 2015; Zwaan, Corti, Sani, et al., 2020, Figure 3) that allow the construction of the first-ever boreholecalibrated structural profiles of the WAM.

\section{Large-Scale Earthquake Analysis}

\subsection{Earthquake Distribution and SMR}

Plotting all available data from the Keir et al. (2006), Belachew et al. (2011) and Illsley-Kemp, Keir, et al. (2018) earthquake catalogs shows intense seismic activity along the rift axes in Afar (Figure 4a). 

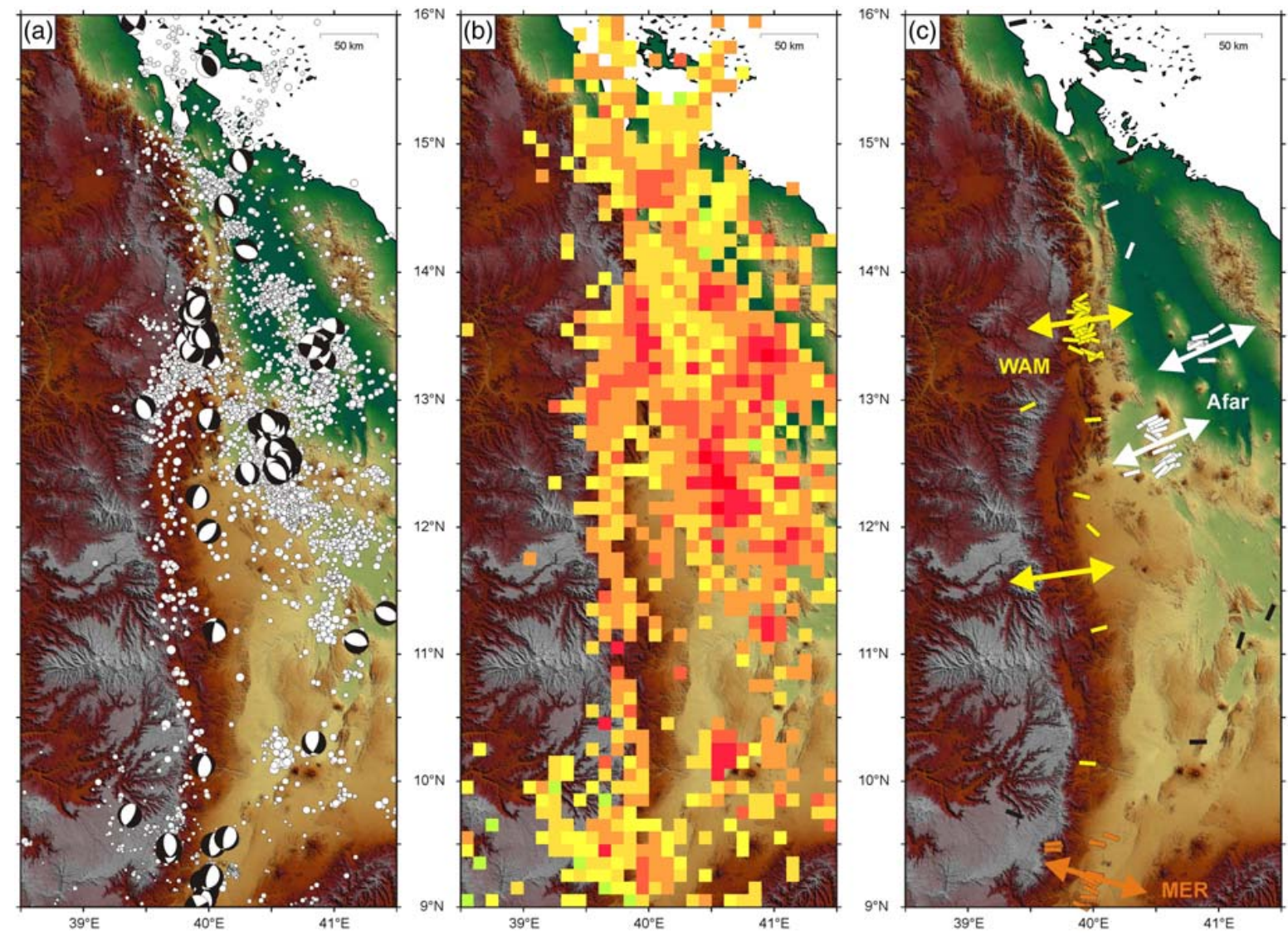

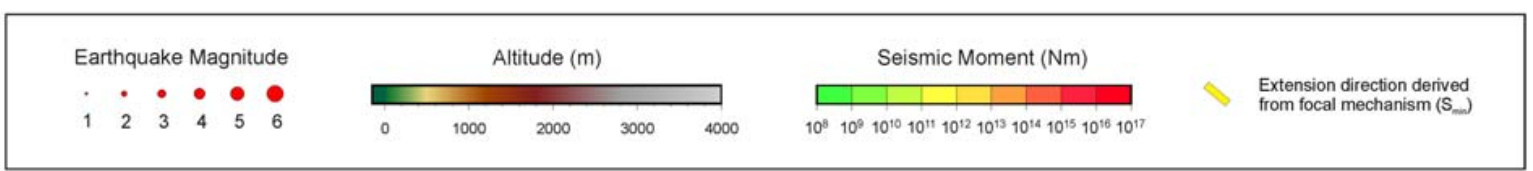
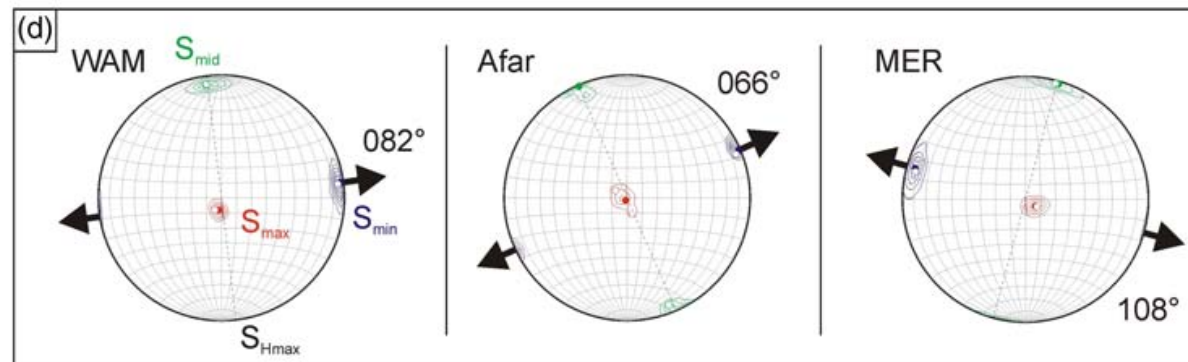

Figure 4. Large-scale earthquake analysis. (a) Map of combined earthquakes from the Keir et al. (2006), Belachew et al. (2011) and Illsley-Kemp, Keir, et al. (2018) datasets (survey periods: 2001-2003, 2007-2009 and 2011-2013, respectively). Focal mechanisms are from the CMT database, Keir et al. (2006), Illsley-Kemp, Bull, et al. (2018), and Illsley-Kemp, Keir, et al. (2018). (b) Seismic moment release (SMR) map of the WAM and nearby Afar, produced with the earthquake data presented in (a). (c) Tectonic stress parameters revealing current extension directions along the Western Afar Margin (WAM), in Afar and along the Main Ethiopian Rift (MER) derived from the earthquake focal mechanisms presented in (a). The general results of the calculation are shown in (d). Background topography is derived from ASTER data (90 m resolution). Map locations shown in Figure 2a.

Here, a distinct right-stepping zigzag pattern emerges, connecting the Danakil rift axis to the north with the Dabbahu segment to the south, perhaps marking structures that transfer strain between both rift axes (e.g., Dumont et al., 2019). Less continuous patches of recorded earthquakes to the south indicate the location of the MER (Figure 4a). Note however, the significant number of seismic events along the sigmoidal trace of the whole WAM, which are most concentrated between ca. $12.5^{\circ} \mathrm{N}$ and $14^{\circ} \mathrm{N}$ (Figure $4 \mathrm{a}$ ). 

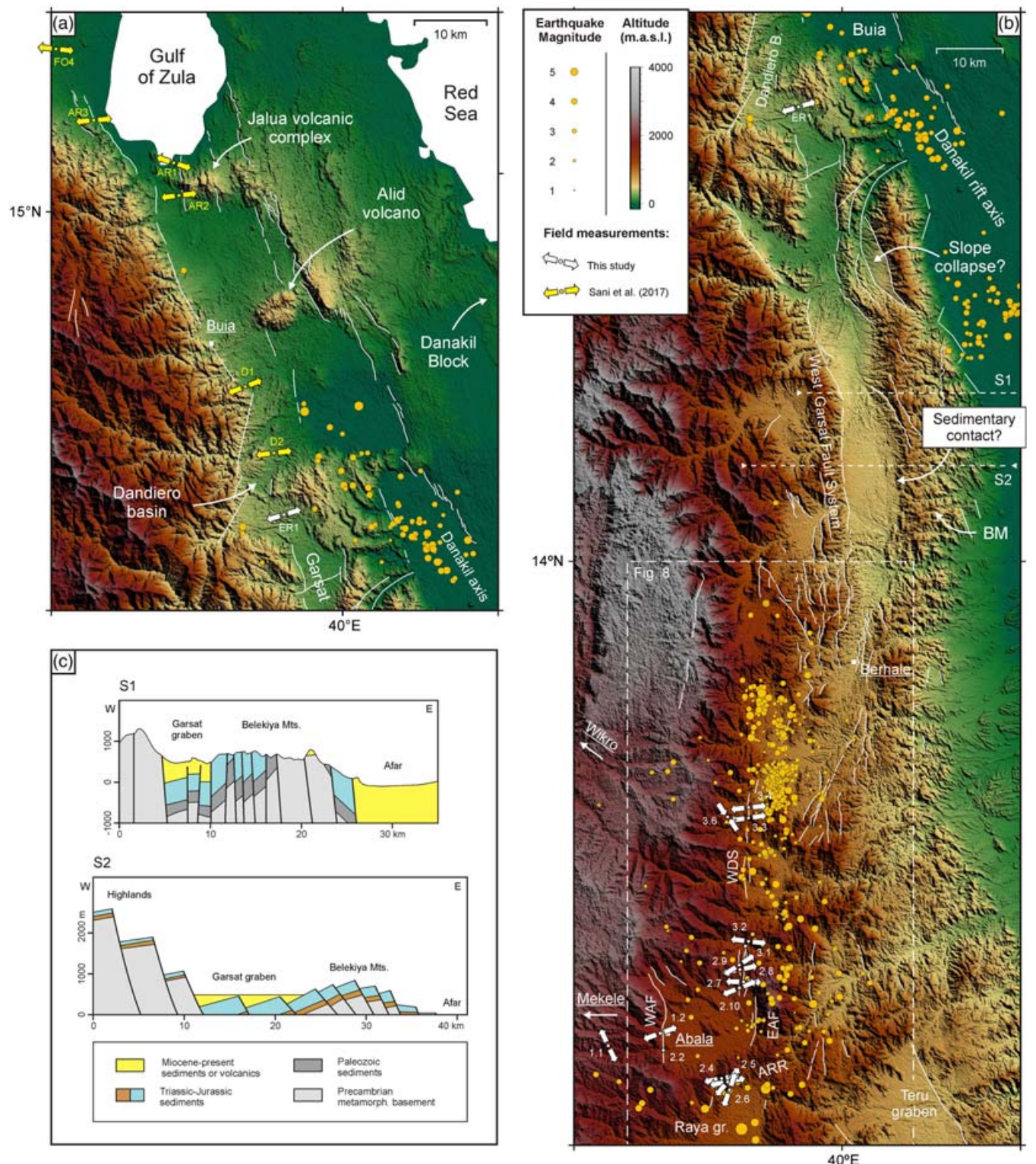

Figure 5. Detailed maps of (a) the Buia graben and (b) Garsat graben. AAR: Abala-Raya Ridge, EAF: East Abala Fault, BM: Belekiya Mountains, WAF: West Abala Fault, WB: Wikro Basin WDS: Wikro Dike Swarm. Note the crescent-shaped depression at NE edge of the Garsat graben, which Chorowicz et al. (1999) interpret as a slope collapse structure. Earthquakes are shown by yellow circles, scaled for magnitude, interpreted faults by white lines. Background topography is derived from ASTER data (90 m resolution). For locations, see Figure 3b. (c) Two contrasting structural interpretations for the SE Garsat graben margin, S1 being the interpretation by Kazmin et al. (1978) involving a faulted contact, whereas Williams (2016) proposes a halfgraben architecture with a sedimentary contact on the basis of data from Garland, (1980) (S2). Hagos et al. (2016) and Le Gall et al. (2018) support the latter option. (Approximate) section locations are indicated in (b).

Although a lower number of earthquakes are recorded in the southern sectors of the WAM due to a lack of seismic stations there, the calculated seismic moment release (SMR) does not show a significant decrease in energy (Figure 4b). This is consistent with the fact that some of the major earthquakes in (recent) Ethiopian history occurred in the southernmost sectors of the WAM, near Ankober and Karakore (Gouin, 1979, Figure 2b). We also clearly observe a high concentration of seismic moment release along the various rift axes in Afar (Figure 4b). Calculations by Illsley-Kemp, Keir, et al. (2018) have shown that these account for $2 / 3$ of the energy release in the Danakil rift axis, whereas the WAM takes up the remaining third in the region north of $12.5^{\circ} \mathrm{N}$. Our data now confirm this distribution for the whole WAM. 


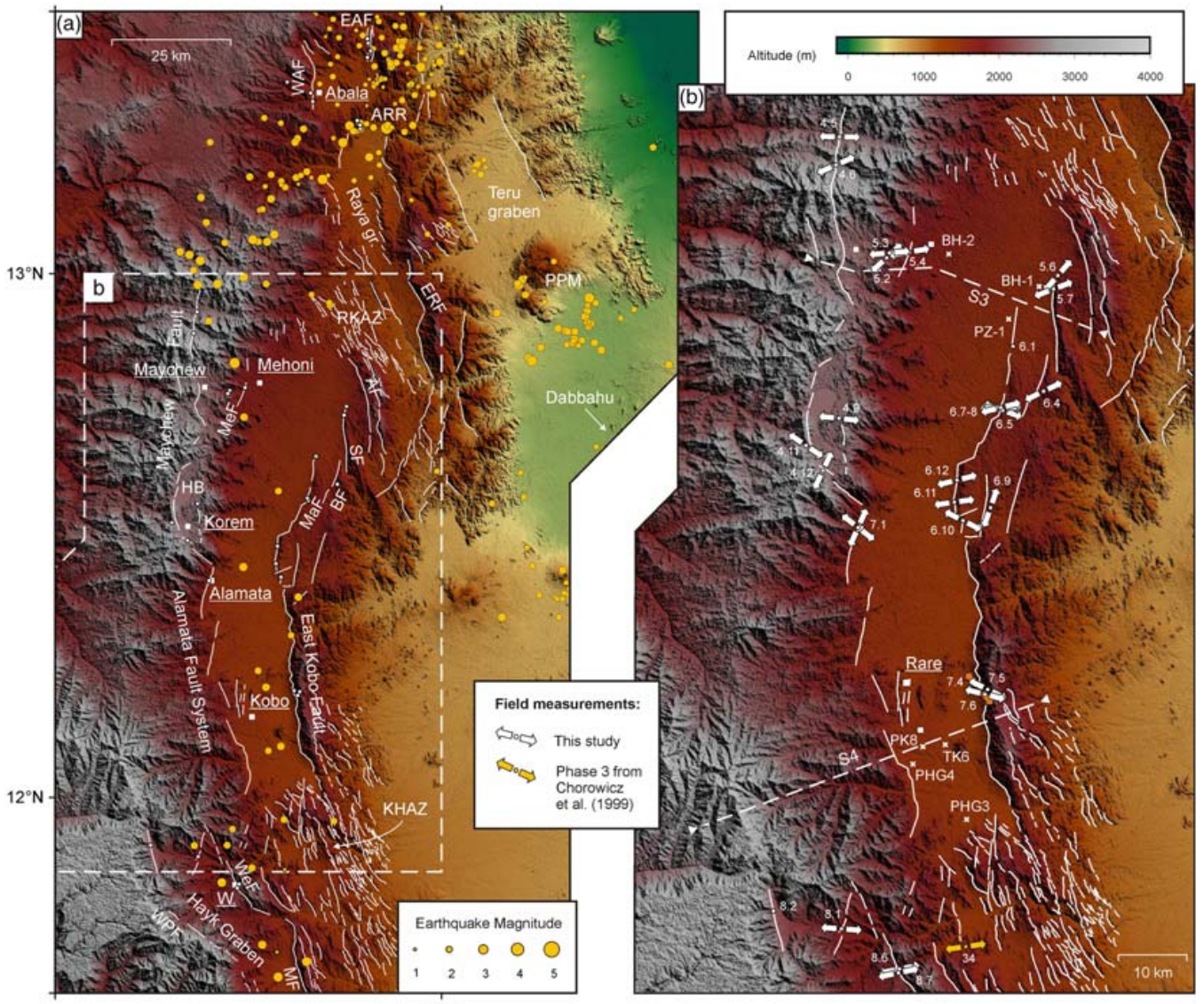

$40^{\circ} \mathrm{E}$
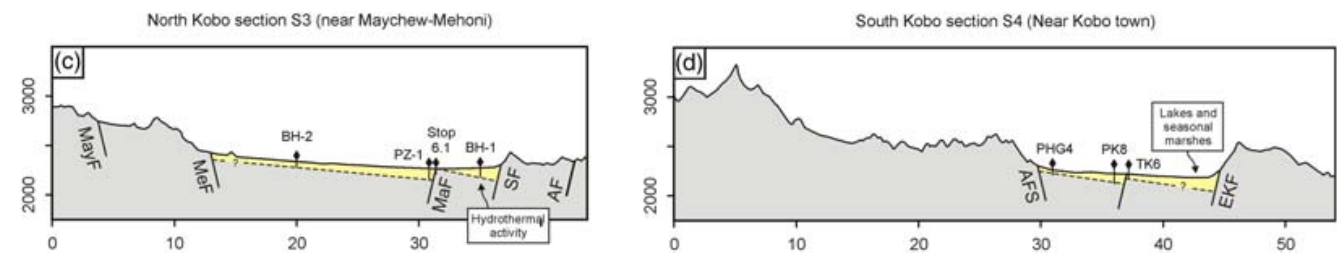

Figure 6. Detailed maps of (a) Kobo-Raya-Teru area and (b) zoom in on the Kobo graben. AF: Abdera Fault, ARR: Abala-Raya Ridge, AsB: Ashenge basin, BF: Bariye Fault, EAF: East Abala Fault, KHAZ: Kobo-Hayk Accommodation Zone, MaF: Manu Fault, MeF: Mehoni Fault, MF: Mersa Fault, PPM: Pierre Pruvost Massif, RKAZ: Raya-Kobo Accommodation Zone; SF: Solaka Fault, W.: Weldiya (town), WAF: West Abala Fault, WeF: Weldiya Fault, WPF: West Plateau Fault. Earthquakes are shown by yellow circles, scaled for magnitude, interpreted faults by white lines. Background topography is derived from ASTER data (90 m resolution). For location, see Figure 3b. (c, d) Well-controlled sections S3 and S4 through the northern and southern sectors of the Kobo graben, respectively. See (b) for well locations, indicated by crosses. Well data are provided in the supplementary material (Zwaan, Corti, Sani, et al., 2020).

\subsection{Tectonic Stress Calculation From Focal Mechanisms}

Earthquakes are a manifestation of a region's tectonic stress field. However, the nonlinear interaction between the stress field and frictional slip on fault planes means it is difficult to draw inferences regarding stress field orientation from individual earthquake focal mechanisms. We separate focal mechanisms from Keir et al. (2006), Illsley-Kemp, Bull, et al. (2018), and Illsley-Kemp, Keir, et al. (2018), and the CGMT database, into geographically distinct regions. We then use a Bayesian method of stress parameter estimation (Arnold \& Townend, 2007), which accounts for errors in nodal plane parameters, to infer tectonic stress parameters for each region. This provides us with a quantitative measure of the current extension direction along the WAM and the adjacent Afar (Figure 4c). The WAM north of $10.5^{\circ} \mathrm{N}$ is characterized by a ca. WSW-ENE extension, of which the cluster east of Mekele provides a statistically significant mean $S_{3}$ $\left(S_{\text {min }}\right)$ strike of $82^{\circ} \mathrm{N}$ (Figures $4 \mathrm{c}$ and $4 \mathrm{~d}$ ). South of $10.5^{\circ} \mathrm{N}$, the $S_{3}$ orientation indicates an east-west 

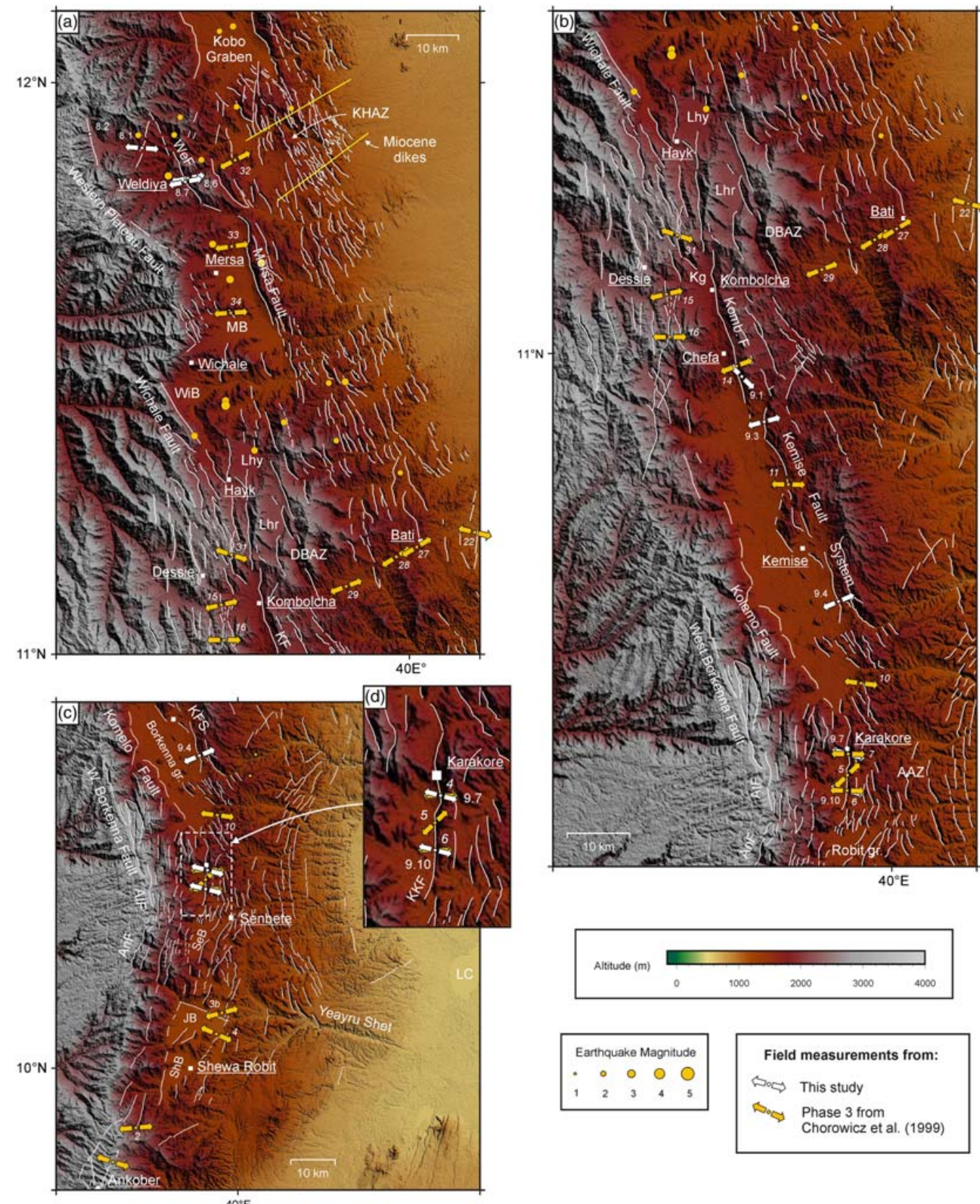

$40^{\circ} \mathrm{E}$

Figure 7. Detailed maps of (a) the Hayk graben area, (b) the Borkenna graben, and (c) the Arcuate Accomodation Zone and Robit graben. AAZ: Arcuate Accommodation Zone, AtF: Ataye Fault, AnF: Ankober Fault, DBAZ: Dessie-Bati Accommodation Zone, Kg: Kombolcha graben, KHAZ: Kobo-Hayk

Accommodation Zone, KKB: Karakore basin, KF: Kombolcha Fault, KKF: Karakore Fault, LC: Lake Caddabassa, Lhr: Lake Haribo, LHy: Lake Hayk, MB: Mersa basin, SeB: Senbete basin, ShB: Sheba basin, WiB: Wichale basin. Earthquakes are shown by yellow circles, scaled for magnitude, interpreted faults by white lines. For location, see Figure $3 \mathrm{~b}$.

extension near Karakore and a more WNW-ESE extension where the margin aligns with the MER. Here, $S_{3}$ has a statistically significant mean trend of $108^{\circ} \mathrm{E}$ (Figures $4 \mathrm{c}$ and $4 \mathrm{~d}$ ). At the Dabbahu segment and along the Danakil rift axis in Afar, extension is slightly more to the NE $\left(66^{\circ} \mathrm{N}\right)$ compared to the WAM (mean extension direction: $82^{\circ} \mathrm{N}$, Figures $4 \mathrm{c}$ and $4 \mathrm{~d}$ ), which is in agreement with the ca. $60^{\circ} \mathrm{N}$ extension at the Danakil axis reported by La Rosa et al. (2019). 

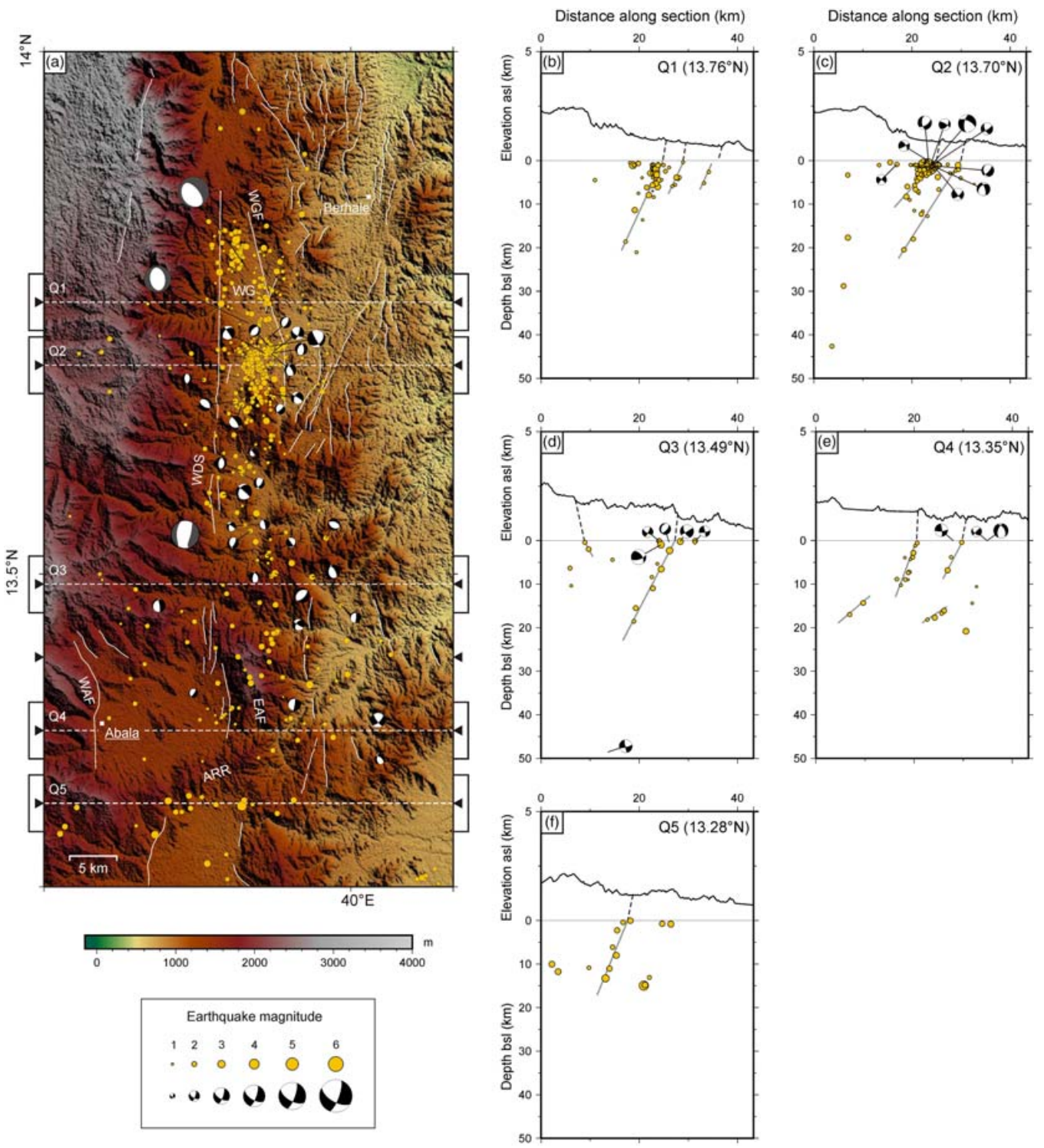

Figure 8. (a) Detailed analysis of the southern Garsat basin/Wikro graben area. Earthquakes shown are a selection from the Illsley-Kemp, Keir, et al. (2018) seismic survey and relocated dataset from Belachew et al. (2011) (selection criteria: xyz error margins $\leq 10 \mathrm{~km}$ ). Gray focal mechanisms are derived from the CMT database, the black focal mechanism from the Illsley-Kemp, Keir, et al. (2018) catalog. ARR: Abala-Raya Ridge, EAF: East Abala Fault, WAF: West Abala Fault, WDS: Wikro Dike Swarm, WG: Wikro graben, WGF: Wikro graben Fault. Earthquakes are shown by yellow circles, scaled for magnitude, interpreted faults by white lines. (b-f) Five E-W sections (Q1-5) showing earthquake clusters indicating active faults (gray lines) and how these may relate to faults visible at the surface (dotted lines). Earthquake swoop width is $6 \mathrm{~km}$ as indicated by the boxes on both sides of the map. For location, see Figure 5b. Topography is derived from ASTER data (90 m resolution).

\section{Structural Mapping}

Detailed maps of every marginal graben area are presented in Figures 5-7, we show the results of detailed earthquake-based fault interpretation in Figure 8, and a general overview of interpreted faults along the WAM are provided in Figures 9a and 9b. The main points of this mapping effort are laid out below, but an exhaustive description of the characteristics of the WAM is made available in the supplementary material (Zwaan, Corti, Sani, et al., 2020). 

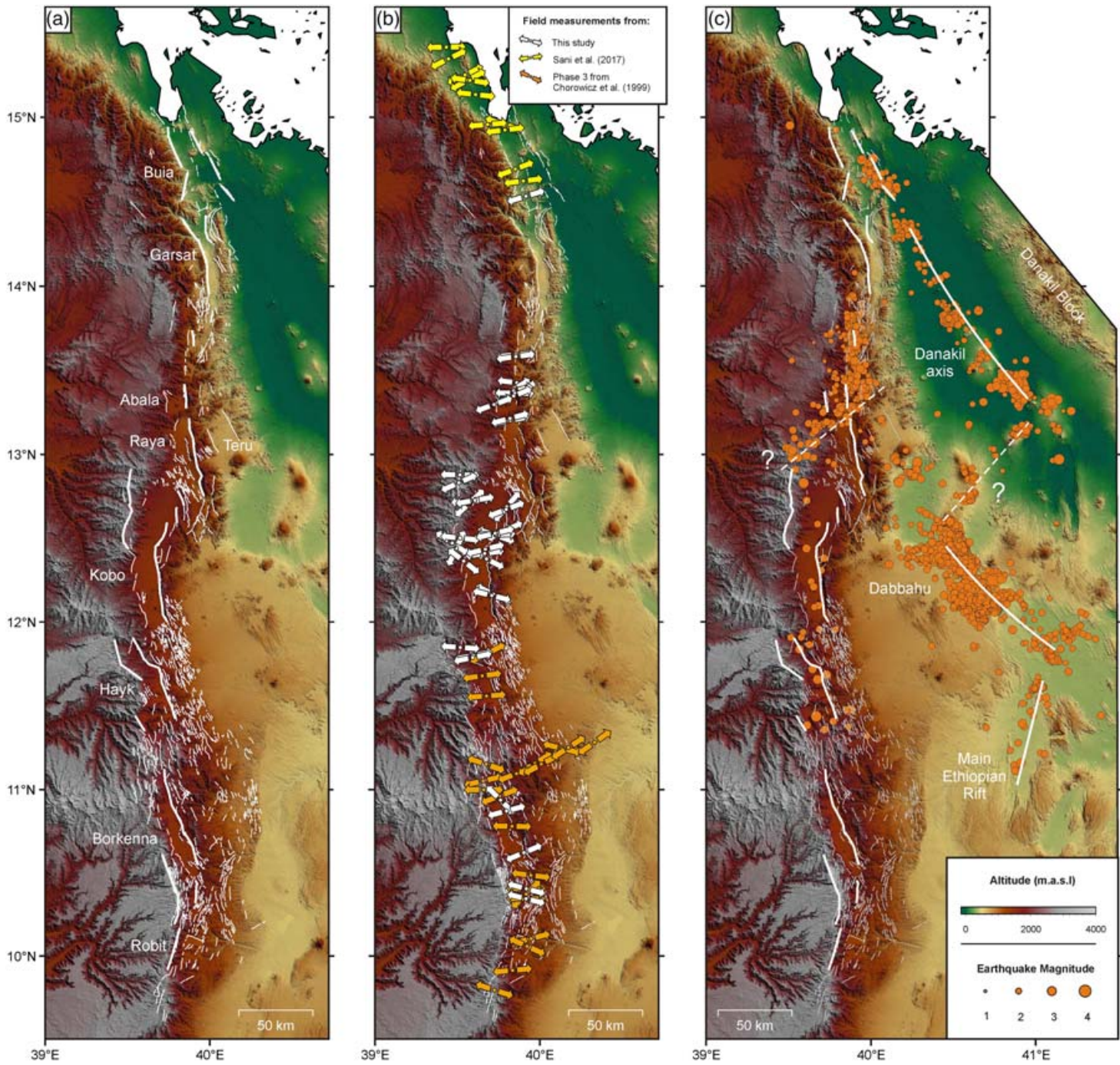

(d) Fault strike derived from fault interpretation

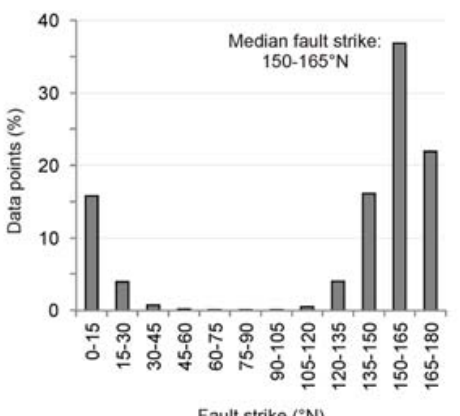

(e) Extension direction derived from field data

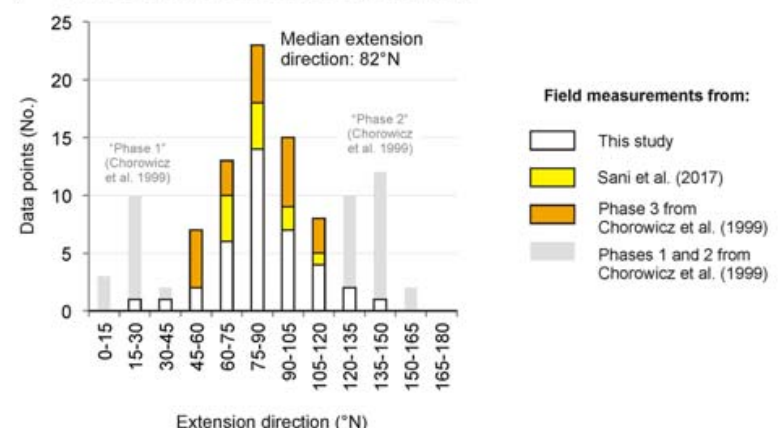

Figure 9. Overview of structural interpretation of the Western Afar Margin (WAM) as derived from DEM and satellite image analysis, as well as the assessment of novel and published field data. (a) WAM fault map as derived from satellite image and topography analysis. Interpreted faults are depicted with thin white lines, whereas thick white lines indicate recently active faults. (b) Combined fault kinematic analysis (data from Chorowicz et al., 1999 ; Sani et al., 2017 and new fieldwork) providing the extension directions of all points along the WAM. (c) Distribution of well-localized seismic events (of $\leq+-5 \mathrm{~km}$ in xyz directions) from our combined earthquake survey and recently active faults, as well as rift axes in Afar. Thick white lines indicate active faults/rift axes. Dotted lines indicate potential transverse structures (e.g., reactivated basement lineaments or rift linkage zones). Background topography is derived from ASTER data (90 m resolution). (d) Quantification of fault orientations along the WAM. (e) Quantification of extension directions derived from fault measurements. 


\subsection{Fault and Marginal Graben Trends}

Although the WAM is aligned north to south, the numerous normal faults we mapped along the margin display a dominant NNW-SSE strike (Figures 5-7, 9a, and 9d). The exception to this is the southernmost part of the WAM, below ca. $10.5^{\circ} \mathrm{N}$, which shows clear fault realignment with the NNE-SSW striking Main Ethiopian Rift (Figures 7b, 7c, and 9a). Naturally, the marginal grabens follow the same trends, and the discrepancy between the general fault alignment and the WAM orientation is accounted for by the presence of various accommodation zones between the marginal grabens. These accommodation zones come in different forms. A minor but well-defined NNE-SSW graben (Dandiero basin) forms the connection between the Buia and Garsat grabens (Figures 5a and 5b). By contrast, the latter is linked to the Abala graben through an NNE-SSW area of rather chaotic topography (Figure 5b). Between the Abala, Raya, Teru, and Kobo grabens lie various ridges with different orientations (Figure 6a). The Teru graben represents an anomaly in that it opens into Afar and is somewhat out of sync with the general right-stepping arrangement (Figure 6a). The northern part of the Hayk graben diverts towards the west, away from the Kobo graben into the Ethiopian plateau, creating a type of overlapping graben zone (Figure 6a). To the south, the Hayk graben transitions into the complex Desi-Bati Accomodation Zone through which it links with the Borkenna graben (Figures $7 \mathrm{a}$ and $7 \mathrm{~b}$ ). The latter at its southern tip sees the faults diverting to N-S and then NNE-SSW over the Arcuate Accomodation Zone that connects the WAM with the Main Ethiopian Rift (Tesfaye et al., 2003, Figure 7b). Here, a second set of faults follows an opposite curve from SSW-NNE to NNW-SSE, giving an "hourglass" shape in map view, possibly marking the initial location of the SW tip of the Arabian Peninsula before Afar rifting (Tesfaye et al., 2003). This transition from the Borkenna to Robit graben through the Arcuate Accomodation Zone is rather gradual (Figures $7 \mathrm{c}$ and $7 \mathrm{~d}$ ).

The type of faulting we observe by means of topography analysis is in general agreement with previous concepts, that is, synthetic escarpment faults west of the marginal grabens and numerous antithetic faults and small tilted fault blocks to their east (Figures 2b, 5-7, and 9). The latter are however much better defined in the southern parts of the WAM, where the Trap basalts are preserved (Figure 3a). In the northern areas (Buia to Raya/Teru grabens), where these basaltic units are removed by erosion (Bosworth et al., 2005; Mohr, 1983a), no clear pervasive antithetic faulting is observed (Figures 5 and 6a).

\subsection{Constraints on Recent Fault Activity}

Fault morphology provides an impression of fault activity, as fresh, uneroded fault scarps indicate recent displacement, which we complement with detailed seismicity analysis using earthquake data with $<10 \mathrm{~km}$ hypocenter error margins, as well as information form boreholes. In the Buia graben, both the western and eastern boundary faults are well-defined (Figure 5a), where the former displaces large Quaternary fan systems (Abbate et al., 2004; Sani et al., 2017). The clear slope breaks along the Garsat graben indicating recently active faults (Figure $5 \mathrm{~b}$ ), although the nature of the eastern graben edge is elusive (fault or sedimentary contact? Figure 5c). No field measurements are available due to the highly erodible schisteous lithology characterizing the basement units (Barberi et al., 1972; Kazmin, 1972; Kazmin et al., 1978, Figure 3a). Well-localized earthquake data in the northernmost part of the WAM (Buia-Garsat) are limited and concentrated along the Danakil axis.

The chaotic zone separating the Garsat and Abala grabens, as well as in the Abala graben itself contain sufficiently concentrated high-quality earthquake data for detailed fault interpretation (Figure 8a). We plot the events on E-W sections (Q1-5, Figure 8), projecting seismicity from $3 \mathrm{~km}$ either side of the profile (Figure 8a). The plots reveal seismicity defining a number of antithetic faults, yet these faults are not always associated with the apparent rift boundary faults in the area (Figures 8b-8f). Our analyses improve upon previous interpretations (Illsley-Kemp, Keir, et al., 2018) and better define the active antithetic fault systems. Section Q1 shows an antithetic fault that may be the eastern boundary fault of the small Wikro graben, as well as some other minor antithetic faults (Figures 8a and 8b). Also section Q2 shows clear antithetic faulting, potentially a continuation of the Wikro Graben Fault from Q1 (Figures 8a and 8b). More to the south in section Q3, the Wikro Dike Swarm seems inactive, yet a possible antithetic fault occurs east of it (Figure 8d), representing a southward continuation of the Wikro Graben seismicity into the zone east of the Abala graben (Figure 8a), also seen in section Q4 (Figure 8e). Section Q4 captures the East Abala Fault, which is aligned with the dominant eastern boundary fault of the Raya graben to the south (Figures $5 \mathrm{~b}$, $6 \mathrm{a}$, and 
8a). The last section (Q5) reveals antithetic fault activity at the Abala-Raya Ridge (Figures 8a and 8f), which is however not clearly associated with a surface fault.

A belt of seismicity is projected to the SW from the Abala-Raya Ridge (Figures 6a and 9c), possibly indicate a reactivated basement structure of perhaps Pan-African origin (e.g., Ghebreab \& Talbot, 2000). Just to the south of this earthquake zone, the northern Kobo sedimentary plain is bordered by a series of rather well-developed eastern boundary faults, whereas a strongly eroded margin occurs in the west (Figure 6a). Yet the significant and linear topographic downstep at the western edge of the northern Kobo plain implies an important, but recently inactive normal fault (Mehoni Fault). Instead, a major active fault system (Maychew Fault) occurs on the plateau to the west, forming the current western boundary fault of the northern Kobo marginal graben structure, which has "stepped back" into the plateau and continues southward to the small Hashenge basin. (Figure 6a). The westward shift of earthquake activity just to the north of the Kobo graben fits well with the prominence of the Maychew Fault (Figures 6a and 9c). Borehole-controlled section S3 (Figures 6a-6c) shows both the Maychew and Mehoni fault in the west, as well as sedimentary infill thickening towards the east (122 $\mathrm{m}$ in well $\mathrm{BH}-2$ and $222 \mathrm{~m}$ in well PZ-1), interrupted by the northern extension of the Bariye Fault (Figures $6 \mathrm{~b}$ and $6 \mathrm{c}$ ). In the east, the $198 \mathrm{~m}$ deep well $\mathrm{BH}-1$ does not reach bedrock and also registers geothermal activity, possibly related to recent faulting. This indicates that deformation is not localized along a single fault in this part of the margin.

In the southern Kobo graben, the scarce seismicity data seems to shift to the prominent East Kobo Fault, whereas its western counterparts are poorly defined (Figures $6 a, 6 b$, and 9c). Wells near Alamata suggest limited (ca. $100 \mathrm{~m}$ ) sediment infill there, whereas PK3-5, and TK1(RE) near Rare indicate thicker deposits towards the east (Figures 6a and 6b). A second structural profile (S4, Figure 6d) south of Kobo town describes a similar trend, with well TK6 indicating a fault step similar to the one in section S3 (Figures 6c and 6d). We have no direct data in the east, but based on geomorphology (fault scarps, depocenter location, Billi, 2015) and data from the wells near Rare, the thickest deposits should occur near the East Kobo Fault (Figure 6b), which likely has accommodated most of the recent deformation in the area.

Seismic data south of the Kobo graben is too scarce for proper analysis, but the boundary faults of the northern Hayk basin are well-defined as they cut into the Ethiopian plateau, indicating ongoing tectonic activity (Figure 7a). The depocenters near the antithetic Mersa Fault and its pronounced morphology imply recent deformation as well. Further south towards the Dessie-Bati Accomodation Zone, numerous well-defined faults are present, suggesting complex active deformation (Figures $7 \mathrm{a}$ and $7 \mathrm{~b}$ ). In the Borkenna area, the antithetic eastern boundary faults are marked by clear slope-breaks, suggesting ongoing deformation, whereas the Kolemo Fault to the west looks relatively eroded (Figure 7b). Yet the Western Borkenna Fault is rather well-defined, as are its equivalents to the south (Ataye and Ankober Faults, Figures $7 \mathrm{~b}$ and 7c). Finally, the Karakore Fault, responsible for the 1961 Karakore seismic crisis (Gouin, 1979), represents the main antithetic fault in the Arcuate Accomodation Zone (Figures 7b-7d).

Geomorphological interpretation supported by detailed earthquake analysis and well data thus suggests some variation in the location of the currently dominant boundary faults in the marginal grabens (i.e., antithetic vs. synthetic graben boundary faults, Figure 9a), yet the large and sudden topographical decline along the whole of the margin (i.e., the escarpment, Figure 3) implies an continuous synthetic boundary fault system that has accommodated significant, $\mathrm{km}$-scale deformation over time, even if segments of it are currently inactive and partially eroded. By comparison, the offsets of the recently active eastern boundary faults are much smaller, and those of the pervasive antithetic faulting small to minimal.

\subsection{Additional Observations}

Between the Garsat and Abala graben, an N-S series of dikes (Wikro Dike Swarm) occurs, which transitions in the East Abala Fault (Figure 5a). Within the Kobo-Hayk Accomodation Zone, a series of ca. SW-NE Miocene dikes (Stab et al., 2016) interrupt the general NNW-SSE fault architecture (Figure 6a). Chorowicz et al. (1999) suggest a relation between the latter dike family and the formation of the northern MER, around $11 \mathrm{Ma}$ (DeMets \& Merkouriev, 2016; Wolfenden et al., 2004 and references therein), causing a short phase of ca. NW-SE extension in the area (see also section 6.3). 
Furthermore, we observe that the floor of most grabens is rather irregular and interrupted by prominent ridges and tilted fault blocks (Figures 5-7). This is likely due to the basins being underfilled as confirmed by our borehole data from the Kobo graben, which forms the largest sedimentary basin along the WAM, revealing marginal graben infill of not more than a couple of hundred meters thick (Figures $6 \mathrm{c}$ and $6 \mathrm{~d}$, Zwaan, Corti, Sani, et al., 2020). The Buia graben with up to $500 \mathrm{~m}$ of sediments forms an exception, but is not a marginal graben sensu stricto since it forms continuation of the Danakil rift axis (Sani et al., 2017; Zwaan, Corti, Keir, \& Sani, 2020, Figure 5a). Indeed, we observe various rivers that cross-cut the margin, draining the marginal grabens and even eroding their limited sedimentary infill (Billi, 2015), so that instead of filling available accommodation space, material is directly transported to the main depocenter in Afar proper. As a result, the extent of sedimentary basins or plains is not always equivalent to the actual marginal graben structure (e.g., the Hayk graben structure is much larger than its sedimentary plains seems to suggest; Figure 7a).

\section{Structural Field Data Analysis}

The original locations of fault measurements used for kinematic analysis, as well as the derived extension directions, are presented in Figures 5-7, of which a regional overview is provided in Figures 9b and 9e. The underlying information (i.e., fault measurements, field photos, and field book) is available in the supplementary materials (Zwaan, Corti, Sani, et al., 2020).

\subsection{Regional Kinematic Interpretation}

Kinematic analysis of our new field data yields an average extension direction between $75^{\circ} \mathrm{N}$ and $90^{\circ} \mathrm{N}$ (Figure 8e). However, we have (except for the fault at point ER1 affecting Quaternary deposits and the 1961 Karakore event, Figures 5a and 7b-7d) no specific age constraints on the fault planes on which our new kinematic measurements were taken, other than they mostly cut Trap basalts and follow the marginal trend. Yet, the mean extension direction is highly compatible with the results obtained by focal mechanism analysis (section 3.2, Figure 4c, 4d, and 9e). Furthermore, since the WAM is still actively deforming, and the various faults we analyzed have likely experienced recent displacement, it is reasonable to infer that the extension directions derived from field measurements represent current tectonics. These results are subsequently complemented with kinematic data from faults affecting Quaternary deposits in Eritrea (Sani et al. 2017), and from the southern WAM (belonging to "phase 3," the youngest, currently active deformation stage reported by Chorowicz et al., 1999). By doing so, we obtain the first field-based overview of recent kinematics covering the whole length of the WAM (Figure 9b). Furthermore, the combined mean extension direction is the same as previously derived from focal mechanism analysis (i.e., $82^{\circ} \mathrm{N}$, section 3.2 , Figures $4 \mathrm{c}, 4 \mathrm{~d}$, and 9e), underscoring the consistency of our interpretation.

Note that some faults in the Kobo and Borkenna areas provide deviating extension directions as well (Figures $6 \mathrm{~b}$ and $7 \mathrm{~b}$ ), which may simply be the result of local stress field changes that are not uncommon in nature (Muirhead \& Katterhorn, 2018; Roberts \& Michetti, 2004) and do not significantly change the outcomes of our analysis. Far to the south, we took fault measurements at two sites along the antithetic Karakore Fault, among which a well-known outcrop containing slickensides that were probably exhumed during the events of 1961 (point 9.10, Fubelli \& Dramis, 2011, Figures 7b and 7c). These indicate pure normal faulting compatible with the shift of extension direction with respect to the northern parts of the WAM (Figures 4c, 4d, and 9b).

\subsection{Evidence of Previous Tectonic Phases}

Although the regional interpretation provides a clear overview of ongoing extension along the WAM, additional kinematic information on preceding tectonic phases was collected in the field. In the Abala area, we find evidence of ca. NNW-SSE extension recorded along ca. E-W striking normal faults oriented subparallel to the main faults of the Jurassic Mekele basin (Alemu et al., 2018; Arkin et al., 1971; Beyth, 1972, Figure 3a, point 1.1. in Figure 5b) and are likely of the same age. Also a phase of NW-SE compression is recorded in Triassic units north of Abala (point 3.6, Figure 5b), possibly related to Early Cretaceous tectonics (Bosellini et al., 2001). Finally, data from point 2.6. suggest a NNE-SSW extension (Figure 5b), perhaps representing an early stage of Afar rifting (Chorowicz et al., 1999, see section 6.3). 


\section{Discussion}

\subsection{Synopsis of Structural Interpretation}

Fault directions are dominantly NNW-SSE along most of the WAM (Figures 9a and 9c), due to the en-echelon right-stepping arrangement of the margin and the associated marginal grabens that follow the same orientation (Figures 9a and 9d). In the accommodation zones between the marginal grabens, faults do curve to a degree, but only south of ca. $10.5^{\circ} \mathrm{N}$, at the Arcuate Accomodation Zone does the prevailing fault trend truly deflect to align with the ca. SSW-NNE striking MER segments. The fault population is dominated by antithetic structures, a feature that is highly developed east of the marginal grabens between $10^{\circ} \mathrm{N}$ and $12^{\circ} \mathrm{N}$, but less prevalent in the northern sectors of the WAM, possibly due to the difference in lithology (Figures 3a, 5-7, and 9a). Furthermore, in various places current fault activity occurs on or along the plateau, as well as along the antithetic faults (Figure 9a). Also, earthquake and well data from the Abala and Kobo area, respectively, clearly indicate recent antithetic fault activity (Figures $6 \mathrm{c}, 6 \mathrm{~d}$, and 8), which fits very well with the concept of ongoing marginal flexure (Abbate \& Sagri, 1969; Kazmin et al., 1980; Wolfenden et al., 2005; Zwaan, Corti, Keir, \& Sani, 2020). Well data also show marginal graben infill to be thin $(<250 \mathrm{~m}$, Figures $6 \mathrm{c}$ and $6 \mathrm{~d}$ ) and in spite of their impact on the landscape, marginal grabens and antithetic faults seem to form relatively small structures with respect to the large-scale (synthetic) escarpment faults that clearly must have accommodated large amounts of displacement over time.

\subsection{Current Tectonic Regime in Afar}

Large-scale earthquake analysis clearly shows that the whole of the WAM is still actively deforming and accounts for $1 / 3$ of all seismic moment release. Subsequently, computing tectonic stress parameters from available focal mechanisms allows us to derive the current extension directions along the WAM, as well as in the adjacent Afar and the northernmost MER (Figures $4 \mathrm{c}$ and $4 \mathrm{~d}$ ). We find a general extension direction of $82^{\circ} \mathrm{N}$ for the WAM, $66^{\circ} \mathrm{N}$ for Afar, and $108^{\circ} \mathrm{N}$ for the MER, respectively (Figures $4 \mathrm{c}$ and $4 \mathrm{~d}$ ).

Integrating our new fault measurements with published data from Chorowicz et al. (1999) and Sani et al. (2017) allows us to further assess the tectonic regime along the whole length of the WAM (Figures $9 \mathrm{~b}$ and 9e). Most faults have a normal fault character and indicate a ca. WSW-ENE extension direction (median: $\mathrm{N} 82^{\circ} \mathrm{E}$ ) that is highly compatible with the focal mechanism stress analysis.

We find that some data points deviate, but these are probably related to preceding tectonic phases (e.g., Jurassic opening of the Mekele basin and Early Cretaceous compression, Alemu et al., 2018; Beyth, 1972; Bosellini et al., 2001, Figure 5b) and potentially earlier phases of Afar rifting (Chorowicz et al., 1999; see section 6.3), or may simply be the result of local stress field changes that are not uncommon in nature (e.g., Muirhead \& Katterhorn, 2018; Roberts \& Michetti, 2004).

Combined with GPS motion from McClusky et al. (2010) and Saria et al. (2014), we can now construct a map of the current tectonics in the region (Figure 10a). We find a curved pattern of extension directions from $\mathrm{N} 82^{\circ} \mathrm{E}$ along the WAM to $\mathrm{N} 66^{\circ} \mathrm{E}$ in Afar and ca. $\mathrm{N} 48^{\circ} \mathrm{E}$ at the Danakil Block. This is also inferred from seismic anisotropy, which shows a local rotation in the direction of maximum horizontal compression $\left(\mathrm{SH}_{\operatorname{Max}}\right.$; Illsley-Kemp et al., 2017). Furthermore, La Rosa et al. (2019) record a ca. $60^{\circ} \mathrm{N}$ extension along the Danakil axis as well. These results are highly compatible with a rotational opening of Afar scenario due to the pivoting of the Danakil Block since ca. 11 Ma (e.g., Chorowicz et al., 1999; Collet et al., 2000; McClusky et al., 2010; Sichler, 1980; Souriot \& Brun, 1992).

There is some evidence of non-rift parallel structures that transfer strain between laterally offset rifts as indicated by the right-stepping zigzag pattern of earthquakes between the Danakil and Dabbahu rift axes (Figures $4 \mathrm{a}, 4 \mathrm{~b}$, and $8 \mathrm{c}$ ). However, while these features represent local complexities linking en-echelon and overlapping rift axes (e.g., Dumont et al., 2019; Pagli et al., 2019), they sit very much within a framework of anticlockwise rotation of the Danakil Block, as shown by GPS measurements and plate reconstructions (e.g., Collet et al., 2000; McClusky et al., 2010).

Finally, in the MER to the south of the WAM, the average extension direction derived from earthquake focal mechanism analysis $\left(\mathrm{N} 108^{\circ} \mathrm{E}\right)$ is similar to that provided by GPS data $\left(\mathrm{N} 96^{\circ} \mathrm{E}\right.$, Saria et al., 2014, Figure 10a), and Nubia-Somalia plate motion analysis (DeMets \& Merkouriev, 2016). This extension direction in 

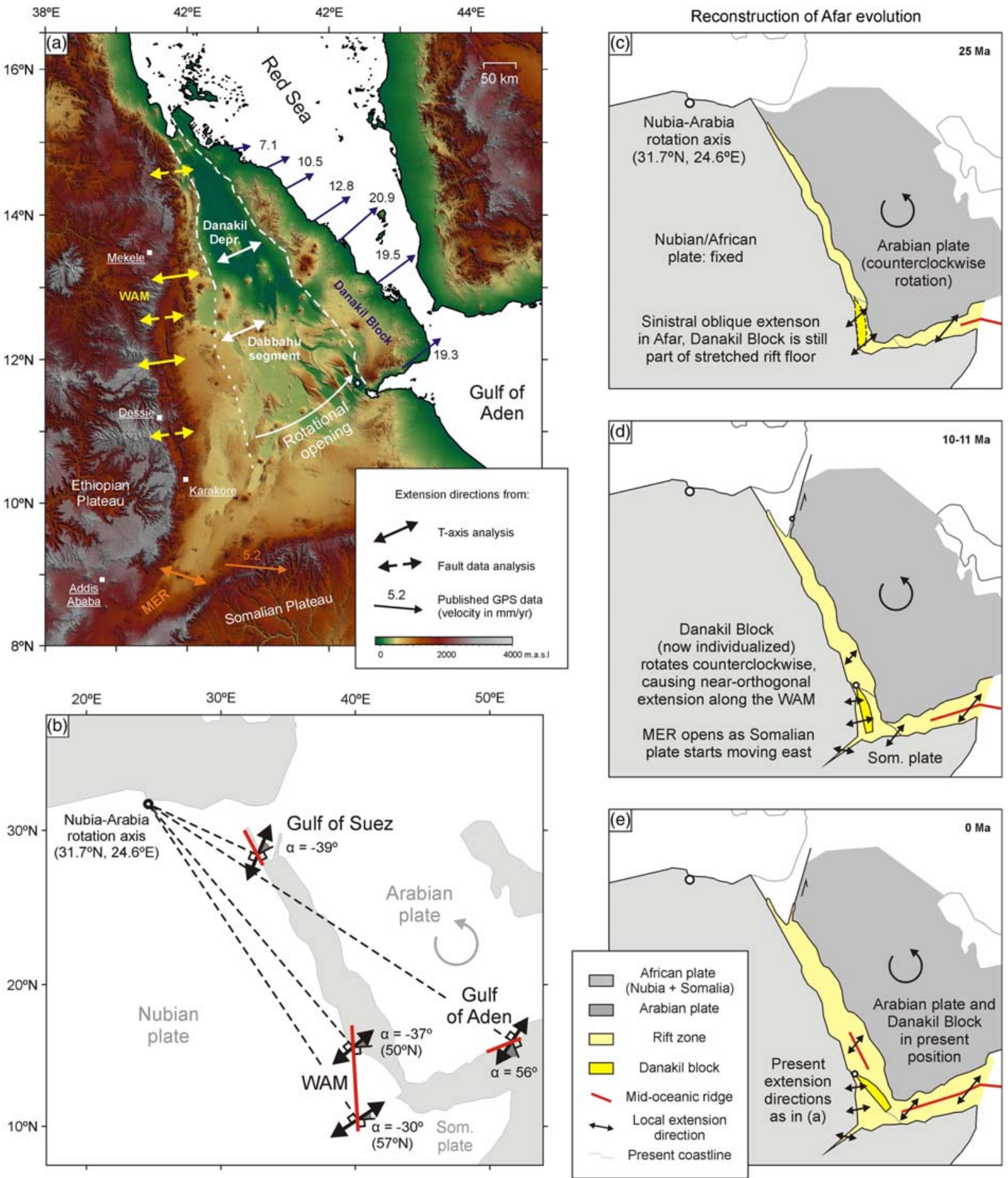

Figure 10. Interpretation of regional tectonics. (a) Combined overview of current tectonic setting in Afar as derived from (1) focal mechanism analysis, (2) field measurements (based on data from Chorowicz et al., 1999; Sani et al., 2017 and this study) and (3) GPS data (McClusky et al., 2010; Saria et al., 2014). MER: Main Ethiopian Rift. (b) Theoretical extension directions (described by angle $\alpha$ between the normal to the rift trend and the general extension direction) in the Red Sea, Gulf of Aden and along the Western Afar Margin (WAM) as a result of the rotation of the Arabian plate about a pole at $31.7^{\circ} \mathrm{N}, 24.6^{\circ} \mathrm{E}(\mathrm{ArRajehi}$ et al., 2010). The ca. N-S orientation of the WAM should result in a ca. NE-SW extension direction $\left(50^{\circ} \mathrm{N}-57^{\circ} \mathrm{N}\right)$ there, similar to the first (sinistral) extension phase described by Chorowicz et al. (1999). Modified after Smith (1993). (c-e) Proposed multiphase evolution of Afar within the regional tectonic framework and effects on extension directions along the WAM. Initial sinistral oblique extension due to the rotation of the Arabian plate (c) is followed by a near-orthogonal extension due to the individual motion of the Danakil block (d-e). Based on Smith (1993), Bosworth et al. (2005), ArRajehi et al. (2010) and Bosworth (2015). 
combination with the orientation of the MER highlights the ongoing sinistral oblique extension there (e.g., Muluneh et al., 2014).

\subsection{Past Tectonic Regime in Afar: The Influence of Arabian Plate Rotation}

By combining data from different sources, we show how the current tectonic regime of Afar is dominated by the rotation of the Danakil Block (Figure 10a). However, rifting in Afar started between 25 and 31 Ma (Ayele et al., 2007; Wolfenden et al., 2005), much earlier than the rotation of this microplate initiated (ca. 11 Ma, McClusky et al., 2010). As pointed out by Smith (1993), the N-S orientation of the WAM in combination with the counterclockwise rotation of the Arabian plate about a pole near Egypt (ArRajehi et al., 2010; McKenzie et al., 1970) demands a local sinistral oblique extension along the margin (Figure 10b), which is comparable to the initial "NE-SW" extension direction reported by Chorowicz et al. (1999, Figure 11b). Such an extension direction along the N-S margin could also elegantly explain the remarkable right-stepping en echelon arrangement of the WAM, which is typical for oblique rifting and can easily reactivate during multiphase rifting, controlling the locus of subsequent faulting (e.g., Bonini et al., 1997; Keep \& McClay, 1997). Similar geometrical relations also explain the oblique fault structures observed in the Gulf of Suez, as well as those along the margins and spreading ridge of the Gulf of Aden (Leroy et al., 2012, Smith, 1993, and references therein, Figures 1a and 10b). The fact that we currently observe an almost E-W extension along the WAM thus indicates a significant local tectonic anomaly, which we can only attribute to the rotational opening of Afar (Kogan et al., 2012).

We therefore propose the following tectonic history of the WAM (Figures 10c-e). Sinistral oblique extension occurred at the start of Afar rifting as the Arabian plate started rotating, and rifting propagated from the Gulf of Aden in the east to the Red Sea in the west (Figures 1, 10c, and 10d). We note that Bosworth et al. (2005) and Bosworth (2015) describe slight variations in extension direction, but these are minor changes and would always cause sinistral oblique extension along the WAM, so that our pure rotational extension model remains valid for a large-scale interpretation. The N-S orientation of the WAM was either controlled by the reactivation of Panafrican lineaments (Chorowicz et al., 1999; Collet et al., 2000; Drury et al., 1994; Ghebreab \& Talbot, 2000) or by the northward extension of the weak lithospheric mantle below Afar forming a distinct rheological contrast (Chang et al., 2011; Hansen \& Nyblade, 2013; Molnar et al., 2017). Initial rifting was distributed (e.g., Stab et al., 2016), leading to a wide rift zone with the later Danakil Block as a part of the extending terrain (Collet et al., 2000; Morton \& Black, 1975; Redfield et al., 2003, Figure 10c). Subsequently, two rift axes (the Red Sea and Danakil axes) formed on both sides of the Danakil Block (Figure 10d). This overlapping rift arrangement caused a modification of the regional tectonic setting and the rotation of the Danakil Block from ca. 11 Ma on (Eagles et al., 2002; Kogan et al., 2012; McClusky et al., 2010; Molnar et al., 2017; Reilinger \& McClusky, 2011). As a result, the local stress field along the WAM is now almost E-W (Figures 4c, 9b, 9e, 10a, 10d and 10e). Around the same time (11 Ma), also the MER became part of the Afar triple junction (Wolfenden et al., 2004, Figure 10d). Based on field data, Chorowicz et al. (1999) propose that the localization of the MER was preceded by a short phase of widespread NW-SE extension. Yet many other studies suggest that extension directions in the MER were always similar to the near E-W extension currently constrained by means of GPS surveys and focal mechanisms, a view we adopted in our reconstruction (DeMets \& Merkouriev, 2016; Saria et al., 2014 and references therein, Figures 4c, 10a, 10d, and 10e).

\subsection{Regional and Global Significance}

In the above paragraph, we describe the structural features of the WAM and how Afar and its western margin have experienced two phases of rotational extension, the first related to the motion of the Arabian plate and the second related to the opening of the Danakil Depression.

As discussed in the review by Zwaan, Corti, Keir, \& Sani (2020), various contrasting scenarios have been proposed to explain the current structural architecture of the WAM, most of which are based on a small area of the WAM and extrapolated over the whole margin. We hope that the data presented in this work will serve as a basis to better constrain the structural evolution of the margin as a whole. Our new data confirm the presence of active antithetic faulting and shallow underfilled marginal grabens, hinting towards recent marginal flexure (e.g., Abbate \& Sagri, 1969; Illsley-Kemp, Keir, et al., 2018; Wolfenden et al., 2005), as well as the influence of multiphase (rotational/oblique) extension and fault reactivation during rifting. Both these factors need to be considered for any complete model.

Afar is often seen as a key location to study continental breakup and passive margin formation in magma-rich environments. Our constraints on extension direction in Afar from fault slip and focal 
mechanism data show significant changes in extension direction over relatively short length scales, best explained by rotational tectonics. This provides further support to the growing body of evidence that plate rotation needs to be considered when interpreting timing of rift initiation, as well as spatial and temporal variations in extension amount and direction (e.g., Molnar et al., 2017, 2018; Mondy et al., 2018; Zwaan, Schreurs, \& Rosenau, 2020). For example, large-scale rotation similar to that of the Arabian plate, as well as associated extension gradients (both in rate and amount of extension) can be found along rift systems worldwide, and various passive margins have experienced changes in extension direction during their evolution (e.g., the NE Atlantic; Brune et al., 2018; Gaina et al., 2009). Furthermore, the ongoing tectonic activity of the WAM after the formation of the magmatic segments in Afar suggests that seafloor spreading is not fully established in Afar. In addition, pervasive antithetic faulting has been observed along various magma-rich passive margins (e.g., the South Atlantic margins, Paton et al., 2017; Norcliffe et al., 2018), and it appears that marginal graben-like structures are in fact present along the Uruguayan margin (Tugend et al., 2018). We conclude that the WAM provides highly valuable insights concerning (magmarich) passive margin development.

\section{Conclusion}

In this paper, we have combined seismicity analysis, large-scale structural interpretation, new and published (field) data and well logs to create an up to date description of the structural framework of the Western Afar Margin (WAM) in East Africa and the associated tectonic implications. We find that:

1. Although Afar is in the final stages of continental breakup and extension has largely shifted from the WAM to central Afar, earthquake and seismic moment release (SMR) data show that significant deformation is still taking place along the whole of the WAM, which is clearly not a "true" passive margin yet.

2. Tectonic stress parameters derived from focal mechanism analysis reveal different extension directions along the WAM $\left(82^{\circ} \mathrm{N}\right)$, Afar $\left(66^{\circ} \mathrm{N}\right)$, and in the Main Ethiopian Rift $\left(108^{\circ} \mathrm{N}\right)$. Analysis of new and published fault measurements also reveals an extension direction of $82^{\circ} \mathrm{N}$ along the WAM.

3. The N-S oriented WAM forms a major transition between the Ethiopian Plateau and Afar and is characterized by NNW-SSE normal faulting, a significant part of these antithetic in nature, and an associated series en echelon marginal grabens.

4. Geomorphology and detailed earthquake analysis suggests that the antithetic faults are currently accommodating significant deformation along the margin. Yet we also find evidence of active deformation at of the Ethiopian Plateau and recognize that the large escarpment faults must have accommodated large amounts of slip over time.

5. We present the first-ever borehole-calibrated sections of the WAM, which highlight the limited sedimentary infill of the marginal grabens and support the interpretation that the antithetic faults are currently accommodating significant deformation along the WAM.

6. Fault kinematic analysis on new fault measurements complemented by published fault data allows us to create the first fault kinematic analysis of the WAM, indicating a current $82^{\circ} \mathrm{N}$ extension direction, highly compatible with the results from focal mechanism analysis.

7. By combining the results of fault kinematic analysis, tectonic stress estimations, and published GPS data, we create an integrated overview of active deformation in Afar, which provides strong evidence that current tectonics in Afar are dominated by the rotation of the Danakil Block and to a lesser degree the opening of the Main Ethiopian Rift.

8. The earlier stages of Afar development (25-11 Ma) were however most likely directly related to the rotation of the Arabian plate and the N-S orientation of the future WAM, the latter possibly as a result of reactivated Pan-African lineaments, and involved sinistral oblique extension creating the characteristic en echelon fault arrangement of the margin. Only after the Danakil started its rotation around $11 \mathrm{Ma}$, the current tectonic regime was emplaced, and the en echelon faults reactivated under near-EW extension.

9. Any complete scenario to explain the structural evolution of the WAM should take into account, among other factors, the multi-phase tectonic history of the WAM, the syntethic escarpment and marginal graben development, as well as the current antithetic fault activity we observe.

10. The findings of this study are not only relevant for a better understanding of the WAM but also for the understanding of the role of (multiphase) oblique and rotational extension during rifting and (magmarich) passive margin evolution in general. 


\section{Data Availability Statements}

Extensive supplementary material is publicly available in the form of a GFZ Data Publication (Zwaan, Corti, Sani, et al., 2020): http://doi.org/10.5880/fidgeo.2020.017.

\section{References}

\section{Acknowledgments}

We would like to thank Tim Greenfield and Emma Chambers for their help with GMT. Said Abdu (Water Resource Mine and Energy office of Tigray, Alamata); Fanuel Sharew, Abrha Shumey, and Berhe Abrha (Water Resource Mine and Energy office of Raya Azebo, Mahoni); Solomon Arbsie (Kobo Girana Valley Development Program, Kobo); and Belay Amberber (Woldia University, Woldiya) are gratefully acknowledged for their help in the field and for providing well logs. We would like to especially express our gratitude to Solomon Belay

Gebreegziabher (Etioder, Addis Ababa) for patiently driving us to every outcrop we fancied. Carolina Pagli, Valentin Rime, and Marco Benvenuti helped us to collect the earthquake data sets and maps of the study area. Fault data analysis was done using Win-Tensor, a software developed by Dr. Damien Delvaux, Royal Museum for Central Africa, Tervuren, Belgium. We thank two anonymous reviewers for their constructive feedback that greatly helped to improve the final work. Kirsten Elger and Matthias Rosenau kindly assisted us to publish the supplementary materials to this paper in the form of an Open Access GFZ Data Publication (Zwaan, Corti, Sani, et al., 2020, http://doi.org/10.5880/fidgeo.2020.017). This project was funded by the Swiss National Science Foundation (Early Postdoc Mobility grant P2BEP2_178523, http://p3.snf. ch/Project-178523) awarded to FZ. FS received financial support from the Ministero Università e Ricerca (grant MiUR-FFABR2017) and the Università degli Studi di Firenze (grant 2018). PRIN grant 2017P9AT72 covered publication costs. FIK is supported by the ECLIPSE program, funded by the New Zealand Ministry of Business Innovation and Employment.
Abbate, E., Bruni, P., \& Sagri, M. (2015). Geology of Ethiopia: A review and geomorphological perspectives. In P. Billi (Ed.), Landscapes and Landforms of Ethiopia, World Geomorphological Landscapes (pp. 33-64). Dordrecht: Springer Science+Business Media. https://doi.org/ 10.1007/978-94-017-8026-1_2

Abbate, E., \& Sagri, M. (1969). Dati e considerazioni sul margine orientale dell'altiplano etiopico nelle province del Tigrai e del Wollo. Bollettino Societa Geologica Italiana, 88, 489-497.

Abbate, E., Woldehaimanot, B., Bruni, P., Falorni, P., Papini, M., Sagri, M., et al. (2004). Geology of the homo-bearing Pleistocene Dandiero Basin (Buia region, Eritrean Danakil depression). Rivista Italiana di Paleontologia e Stratigrafia, 110, 5-34. https://doi.org/10.13130/ 2039-4942/5761

Alemu, T., Abdelsalam, M. G., Dawit, E. L., Atnafu, B., \& Mickus, K. L. (2018). The Paleozoic e Mesozoic Mekele Sedimentary Basin in Ethiopia: An example of an exhumed IntraCONtinental sag (ICONS) basin. Journal of African Earth Sciences, 143, 40-58. https://doi. org/10.1016/j.jafrearsci.2018.03.010

Argent, J. D., Stewart, S. A., \& Underhill, J. R. (2000). Controls on the lower cretaceous punt sandstone Member, a massive deep-water clastic deposystem, inner Moray firth, UK North Sea. Petroleum Geoscience, 6, 275-285. https://doi.org/10.1144/petgeo.6.3.275

Arkin, Y., Beyth, M., Dow, D. B., Levitte, D., Temesgen, H., \& Tsegaye, H. (1971). Geological Map of Mekele Sheet Area Sheet ND 37-11, Tigre province. Imperial Ethiopian Government, Ministry of Mines, Geological Survey of Ethiopia, Addis Ababa.

Arnold, R., \& Townend, J. (2007). A Bayesian approach to estimating tectonic stress from seismological data. Geophysical Journal International, 170, 1336-1356. https://doi.org/10.1111/j.1365-246X.2007.03485.X

ArRajehi, A., McCluskey, S., Reilinger, R., Daoud, M., Alchalbi, A., Egintav, S., et al. (2010). Geodetic constraints on present-day motion of the Arabian Plate: Implications for Red Sea and Gulf of Aden rifting. Tectonics, 29, TC3011. https://doi.org/10.1029/2009TC002482

Augustin, N., Devey, C. W., Van der Zwan, F. M., Feldens, P., Tominaga, M., Bantan, R. A., \& Kwasnitschka, T. (2014). The rifting to spreading transition in the Red Sea. Earth and Planetary Science Letters, 395, 217-230. https://doi.org/10.1016/j.epsl.2014.03.047

Ayalew, D., Ebinger, C., Bourdon, E., Wolfenden, E., Yirgu, G., \& Grassineau, N. (2006). Temporal compositional variation of syn-rift rhyolites along the western margin of the southern Red Sea and northern Main Ethiopian Rift. In G. Yirgu, C. J. Ebinger, \& P. K. H. Maguire (Eds.), The Afar Volcanic Province within the East African Rift System, Geological Society, London, Special Publications (Vol 259, 121-130). https://doi.org/10.1144/GSL.SP.2006.259.01.10

Ayalew, D., Pik, R., Bellahsen, N., France, L., \& Yirgu, G. (2019). Differential fractionation of rhyolites during the course of crustal extension, Western Afar (Ethiopian Rift). Geochemistry, Geophysics, Geosystems, 20, 571-593. https://doi.org/10.1029/2018GC007446

Ayele, A., Stuart, G., Bastow, I., \& Keir, D. (2007). The August 2002 earthquake sequence in North Afar: Insights into the neotectonics of the Danakil microplate. Journal of African Earth Sciences, 48, 70-79. https://doi.org/10.1016/j.jafrearsci.2006.06.011

Baker, B. H., Mohr, P. A., \& Williams, L. A. J. (1972). Geology of the Eastern Rift System of Africa. GSA Special Paper 136. https://doi.org/ 10.1130/SPE136

Barberi, F., Borsi, S., Ferrara, G., Marinelli, G., \& Varet, J. (1970). Relations between tectonics and magmatology in the northern Danakil depression (Ethiopia). Philosophical Transactions of the Royal Society A: Mathematical, Physical and Engineering Sciences, 267, 293-311. https://doi.org/10.1098/rsta.1970.0037

Barberi, F., Giglia, G., Marinelli. G., Santecroce, R., Tazieff, H., Varet, J. et al. (1972). Geological map of the Danakil depression. Société GÉOTECHNIP 78, la Celle-Saint Cloud, France.

Barberi, F., \& Santacroce, R. (1980). The Afar Stratoid series and the magmatic evolution of East African Rift System. Bulletin de la Société Géologique de France S7-XXII, 891-899. https://doi.org/10.2113/gssgfbull.S7-XXII.6.891

Barberi, F., \& Varet, J. (1977). Volcanism of Afar: Small-scale plate tectonics implications. GSA Bulletin, 88, 1251-1266. https://doi.org/ 10.1130/0016-7606(1977)88<1251:VOASPT >2.0.CO;2

Barnie, T. D., Keir, D., Hamling, I., Hofmann, B., Belachew, M., Carn, S., et al. (2015). A multidisciplinary study of the final episode of the Manda Hararo dyke sequence, Ethiopia, and implications for trends in volcanism during the rifting cycle. In T. J. Wright, A. Ayele, D. J. Ferguson, T. Kidane \& C. Vye-Brown (Eds.). Magmatic Rifting and Active Volcanism, Geological Society, London, Special Publications (Vol. 420, pp. 149-163). https://doi.org/10.1144/SP420.6

Belachew, M., Ebinger, C., Coté, D., Keir, D., Rowland, J. V., Hammond, J. O. S., \& Ayele, A. (2011). Comparison of dike intrusions in an incipient seafloor-spreading segment in Afar, Ethiopia: Seismicity perspectives. Journal of Geophysical Research, 116, B06405. https:// doi.org/10.1029/2010JB007908

Bellahsen, N., Facenna, C., Funiciello, F., Daniel, J. M., \& Jolivet, L. (2003). Why did Arabia separate from Africa? Insights from 3-D laboratory experiments. Earth and Planetary Science Letters, 216, 365-381. https://doi.org/10.1016/S0012-821X(03)00516-8 Berhe, S. M. (1985). Geological Map of Dire Dawa (Sheet NC37-12). Addis Ababa: Ethiopian Institute of Geological Surveys.

Berhe, S. M. (1986). Geologic and geochronologic constraints on the evolution of the Red Sea-Gulf of Aden and Afar depression. Journal of African Earth Sciences, 5, 101-117. https://doi.org/10.1016/0899-5362(86)90001-1

Beyene, A., \& Abdelsalam, M. G. (2005). Tectonics of the Afar Depression: A review and synthesis. Journal of African Earth Sciences, 41, 41-59. https://doi.org/10.1016/j.jafrearsci.2005.03.003

Beyth, M. (1972). Paleozoic-Mesozoic Sedimentary Basin of Mekele Outlier, Northern Ethiopia. AAPG Bulletin, 56, 2426-2439. https://doi. org/10.1306/819A422A-16C5-11D7-8645000102C1865D

Billi, P. (2015). Geomorphology of ephemeral streams in the Kobo Basin. In P. Billi(Ed.), Landscapes and Landformes of Ethiopia (213-225). Dordrecht: Springer Science and Business Media. https://doi.org/10.1007/978-94-017-8026-1_12

Bonini, M., Souriot, T., Boccaletti, M., \& Brun, J. P. (1997). Successive orthogonal and oblique extension episodes in a rift zone: Laboratory experiments with application to the Ethiopian Rift. Tectonics, 16(2), 347-362. https://doi.org/10.1029/96TC03935

Bosellini, A., Russo, A., \& Assefa, G. (2001). The Mesozoic succession of Dire Dawa, Harar Province, Ethiopia. Journal of African Earth Sciences, 32, 403-417. https://doi.org/10.1016/S0899-5362(01)90105-8 
Bosworth, W. (2015). Geological evolution of the Red Sea: Historical background, review, and synthesis. In N. Rasul, \& I. Stewart (Eds.), The Red Sea (45-78). Berlin, Heidelberg: Springer Earth System Sciences. Springer. https://doi.org/10.1007/978-3-662-45201-1_3

Bosworth, W., Huchon, P., \& McClay, K. (2005). The Red Sea and Gulf of Aden Basins. Journal of African Earth Sciences, 43, 334-378. https://doi.org/10.1016/j.jafrearsci.2005.07.020

Brune, S. (2016). Rifts and rifted margins: A review of geodynamic processes and natural hazards. In J. C. Duarte, \& W. P. Schellart (Eds.), Plate Boundaries and Natural Hazards, AGU Geophysical Monograph (Vol. 219, pp. 11-37). Washington, DC: AGU. https://doi.org/ 10.1002/9781119054146.ch2

Brune, S., Williams, S. E., \& Müller, R. D. (2018). Oblique rifting: The rule, not the exception. Solid Earth, 9, 1187-1206. https://doi.org/ $10.5194 / \mathrm{se}-9-1187-2018$

Catuneanu, O., Abreu, V., Bhattacharya, J. P., Blum, M. D., Dalrymple, R. W., Eriksson, P. G., et al. (2009). Towards the standardization of sequence stratigraphy. Earth-Science Reviews, 92, 1-33. https://doi.org/10.1016/j.earscirev.2008.10.003

Chang, S.-J., Merino, M., van der Lee, S., Stein, S., \& Stein, C. A. (2011). Mantle flow beneath Arabia offset from the opening Red Sea. Geophysical Research Letters, 38, L04301. https://doi.org/10.1029/2010GL045852

Chorowicz, J., Collet, B., Bonavia, F., \& Korme, T. (1999). Left-lateral strike-slip tectonics and gravity induced individualisation of wide continental blocks in the western Afar margin. Eclogae Geologicae Helvetiae, 92, 149-158. http://doi.org/10.5169/ seals- 168656

Craig, T. J., Jackson, J. A., Priestley, Priestley, \& McKenzie, D. (2011). Earthquake distribution patterns in Africa: Their relationship to variations in lithospheric and geological structure, and their rheological implications. Geophysical Journal International, 185, 403-434. https://doi.org/10.1111/j.1365-246X.2011.04950.x

Cochran, J. R. (2005). Northern Red Sea: Nucleation of an oceanic spreading center within a continental rift. Geochemistry, Geophysics, Geosystems, 6, Q03006. https://doi.org/10.1029/2004GC000826

Collet, B., Taud, H., Parrot, J. F., Bonavia, F., \& Chorowicz, J. (2000). A new kinematic approach for the Danakil block using a Digital Elevation Model representation. Tectonophysics, 316, 343-357. https://doi.org/10.1016/S0040-1951(99)00263-2

Coltorti, M., Dramis, F., \& Ollier, C. D. (2007). Planation surfaces in northern Ethiopia. Geomorphology, 89, 287-296. https://doi.org/ 10.1016/j.geomorph.2006.12.007

Coltorti, M., Firuzabadi, D., Borri, A., Fantozzi, P., \& Pieruccini, P. (2015). Planation surfaces and the long-term geomorphological evolution of Ethiopia. In P. Billi (Ed.), Landscapes and Landformes of Ethiopia (pp. 117-136). Dordrecht: Springer Science and Business Media. https://doi.org/10.1007/978-94-017-8026-1_5

Corti, G., Bastow, I. D., Keir, D., Pagli, C., \& Baker, E. (2015). Rift-Related Morphology of the Afar Depression. In P. Billi (Ed.), Landscapes and Landforms of Ethiopia, World Geomorphological Landscapes (pp. 251-274). Dordrecht: Springer Science and Business Media. https://doi.org/10.1007/978-94-017-8026-1_15

D'Acremont, E., Leroy, S., Maia, M., Patriat, P., Berslier, M. O., Bellahsen, N., et al. (2006). Structure and evolution of the eastern Gulf of Aden: insights from magnetic and gravity data (Encens-Sheba MD117 cruise). Geophysical Journal International, 165, 786-803. https://doi.org/10.1111/j.1365-246X.2006.02950.x

D'Acremont, E., Leroy, S., Maia, M., Gente, P., \& Autin, J. (2010). Volcanism, jump and propagation on the Sheba ridge, eastern Gulf of Aden: Segmentation evolution and implications for oceanic accretion processes. Geophysical Journal International, 180(2), 535-551. https://doi.org/10.1111/j.1365-246X.2009.04448.x

Davison, I., Al-Kadasi, M., Al-Khirbash, S., Al-Subbary, A. K., Baker, J., Blakey, S., et al. (1994). Geological evolution of the southeastern Red Sea Rift margin, Republic of Yemen. Geological Society of America Bulletin, 106, 1474-1493. https://doi.org/10.1130/0016-7606 (1994) $106<1474$ :GEOTSR $>2.3$. CO;2

Davison, I., Tatnell, M. R., Owen, L. A., Jenkins, G., \& Baker, J. (1998). Tectonic geomorphology and rates of crustal processes along the Red Sea margin, north-west Yemen. In B. H. Purser, \& D. W. J. Bosence (Eds.), Sedimentation and Tectonics in Rift Basins: Red Sea-Gulf of Aden (pp. 595-612). London: Chapman and Hall. https://doi.org/10.1007/978-94-011-4930-3_32

Davison, I., \& Underhill, J. R. (2012). Tectonics and Sedimentation in Extensional Rifts: Implications for Petroleum Systems. In D. Gao (Ed.), Tectonics and Sedimentation: Implications for Petroleum Systems, AAPG Memoir (Vol. 100, pp. 15-42). AAPG. https://doi.org/ $10.1306 / 13351547 \mathrm{M} 1001556$

Delvaux, D., \& Sperner, B. (2003). New aspects of tectonic stress inversion with reference to the TENSOR program. In: Nieuwland, D. (ed) New insights into structural interpretation and modelling. Geological Society, London, Special Publications, 212, 75-100. https://doi.org/ 10.1144/GSL.SP.2003.212.01.06

DeMets, C., \& Merkouriev, S. (2016). High-resolution estimates of Nubia-Somalia plate motion since 20 Ma from reconstructions of the Southwest Indian Ridge, Red Sea and Gulf of Aden. Geophysical Journal International, 207, 317-332. https://doi.org/10.1093/ gii/ggw276

Drury, S. A., Kelley, S. P., Berhe, S. M., Collier, R. E. L., \& Abraha, M. (1994). Structures related to Red Sea evolution in northern Eritrea. Tectonics, 13, 1371-1380. https://doi.org/10.1029/94TC01990

Dumont, S., Klinger, Y., Socquet, A., Escartín, J., Grandin, R., Jacques, E., et al. (2019). Rifting Processes at a Continent-Ocean Transition Rift Revealed by Fault Analysis: Example of Dabbahu-Manda-Hararo Rift (Ethiopia). Tectonics, 38, 190-214. https://doi.org/10.1029/ 2018 TC005141

Dziewonski, A. M., Chou, T.-A., \& Woodhouse, J. H. (1981). Determination of earthquake source parameters from waveform data for studies of global and regional seismicity. Journal of Geophysical Research, 86, 2825-2852. https://doi.org/10.1029/JB086iB04p02825

Eagles, G., Gloaguen, R., \& Ebinger, C. (2002). Kinematics of the Danakil microplate. Earth and Planetary Science Letters, 203, 607-620. https://doi.org/10.1016/S0012-821X(02)00916-0

Ebinger, C. J., Keir, D., Ayele, A., Calais, E., Wrigth, T. J., Belachew, M., et al. (2008). Capturing magma intrusion and faulting processes during continental rupture: Seismicity of the Dabbahu (Afar) rift. Geophysical Journal International, 174, 1138-1152. https://doi.org/ 10.1111/j.1365-246X.2008.03877.x

Ekström, G., Nettles, M., \& Dziewonski, A. M. (2012). The global CMT project 2004-2010: Centroid-moment tensors for 13,017 earthquakes. Physics of the Earth and Planetary Interiors, 200-201, 1-9. https://doi.org/10.1016/j.pepi.2012.04.002

Fazzini, M., Bisci, C., \& Billi, P. (2015). The Climate of Ethiopia. In P. Billi (Ed.), Landscapes and Landformes of Ethiopia (65-87). Dordrecht: Springer Science and Business Media. https://doi.org/10.1007/978-94-017-8026-1_3

Fournier, M., Chamot-Rooke, N., Petit, C., Huchon, P., Al-Kathiri, A., Audin, L., et al. (2010). Arabia-Somalia plate kinematics, evolution of the Aden-Owen-Carlsberg triple junction, and opening of the Gulf of Aden. Journal of Geophysical Research, 115, B04102. https://doi. org/10.1029/2008jb006257 
Fubelli, G., \& Dramis, F. (2011). Coseismic surface faulting in the Kara Kore area (Wollo) caused by the May 29, 1961 Earthquake. In J. Nyssen, A. Asrat, F. Dramis \& M. Umer (Eds.). Pre-conference excursion guide: tectonic landforms and volcanism in the Southern Afar. Addis Ababa, Ethiopia: IAG regional conference 2011 geomorphology for human adaptation to changing tropical environments. 18-22 Feb 2011, 5-7.

Gaina, C., Gernigon, L., \& Ball, P. (2009). Palaeocene-Recent plate boundaries in the NE Atlantic and the formation of the Jan Mayen microcontinent. Journal of the Geological Society, London, 166, 601-616. https://doi.org/10.1144/0016-76492008-112

Gani, N. D. S., Gani, M. R., \& Abdelsalam, M. G. (2007). Blue Nile incision on the Ethiopian Plateau: Pulsed plateau growth, Pliocene uplift, and hominin evolution. GSA today 17. https://doi.org/10.1130/GSAT01709A.1

Garland, C. B. (1980). Geology of the Adigrat Area. Provisional Military Govt. of Socialist Ethiopia, Ministry of Mines, Energy \& Water Resources, Geological Survey of Ethiopia.

Geoffroy, L., Huchon, P., \& Khanbari, K. (1998). Did Yemeni tertiary granites intrude neck zones of a stretched continental upper crust? Terra Nova, 10, 196-200. https://doi.org/10.1046/j.1365-3121.1998.00194.x

Ghebreab, W., \& Talbot, C. J. (2000). Red Sea extension influenced by Pan-African tectonic grain in eastern Eritrea. Journal of Structural Geology, 22, 931-946. https://doi.org/10.1016/S0191-8141(00)00022-5

Goitom, B., Werner, M. J., Goda, K., Kendall, J.-M., Hammond, J. O. S., Ogubazghi, G., et al. (2017). Probabilistic Seismic-Hazard Assessment for Eritrea. Bulletin of the Seismological Society of America, 107, 1478-1494. https://doi.org/10.1785/0120160210

Gouin, P. (1970). A discussion on the structure and evolution of the Red Sea and the nature of the Red Sea, Gulf of Aden and Ethiopia rift junction - Seismic and gravity data from Afar in relation to surrounding areas. Philosophical transactions of the Royal Society of London. Series A. Mathematical and Physical Sciences, 267, 339-358. http://doi.org/10.1098/rsta.1970.0040

Gouin, P. (1979). Earthquake History of Ethiopia and the Horn of Africa. Ottawa: International Development Research Centre.

Hagos, M., Konko, B., \& Ahmed, J. (2016). A preliminary Geological and Generalized Stratigraphy of Western Margin of Northern Afar Depression, Dallol Area, Northern Ethiopia. Momona Ethiopian Journal of Science, 8, 1-22. https://doi.org/10.4314/ mejs.v8i1.1

Hammond, J. O. S., Kendall, J.-M., Stuart, G. W., Keir, D., Ebinger, C., Ayele, A., \& Belachew, M. (2011). The nature of the crust beneath the Afar triple junction: Evidence from receiver functions. Geochemistry, Geophysics, Geosystems, 12, Q12004. https://doi.org/10.1029/ $2011 \mathrm{GC} 003738$

Hansen, S., \& Nyblade, A. A. (2013). The deep seismic structure of the Ethiopia/Afar hotspot and the African superplume. Geophysical Journal International, 194, 118-124. https://doi.org/10.1093/gji/ggt116

Haq, B. U., Hardenbol, J., \& Vail, P. R. (1987). Chronology of Fluctuating Sea Levels since the Triassic. Science, 235(4793), 1156-1167. https://doi.org/10.1126/science.235.4793.1156

Hayward, N. J., \& Ebinger, C. J. (1996). Variations in the along-axis segmentation of the Afar Rift system. Tectonics, 15, 244-257. https://doi. org/10.1029/95TC02292

Hoffmann, C., Courtillot, V., Féraud, G., Rochetter, P., Yirgu, G., Ketefo, E., \& Pik, R. (1997). Timing of the Ethiopian flood basalt event and implications for plume birth and global change. Nature, 389, 838-841. https://doi.org/10.1038/39853

Hofstetter, R., \& Beyth, N. (2003). The Afar Depression: Interpretation of the 1960-2000 earthquakes. Geophysical Journal International, 155, 715-732. https://doi.org/10.1046/j.1365-246X.2003.02080.x

Illsley-Kemp, F., Bull, J. M., Keir, D., Gerya, T., Pagli, C., Gernon, T., et al. (2018). Initiation of a Proto-transform Fault Prior to Seafloor Spreading. Geochemistry, Geophysics, Geosystems, 19, 4744-4756. https://doi.org/10.1029/2018GC007947

Illsley-Kemp, F., Keir, D., Bull, J. M., Gernon, T. M., Ebinger, C., Ayele, A., et al. (2018). Seismicity During Continental Breakup in the Red Sea Rift of Northern Afar. Journal of Geophysical Research: Solid Earth, 123, 2345-2362. https://doi.org/10.1002/2017JB014902

Illsley-Kemp, F., Savage, M. K., Keir, D., Hirschberg, H. P., Bull, J. M., Gernon, T. M., et al. (2017). Extension and stress during continental breakup: Seismic anisotropy of the crust in Northern Afar. Earth and Planetary Science Letters, 477, 41-51. https://doi.org/10.1016/j. eps1.2017.08.014

Izzeldin, A. Y. (1987). Seismic, gravity and magnetic surveys in the central part of the Red Sea: their interpretation and implications for the structure and evolution of the Red Sea. Tectonophysics, 143, 269-306. https://doi.org/10.1016/0040-1951(87)90214-9

Kazmin, V. (1972). Geological Map of Ethiopia. Geological Survey of Ethiopia, Ministry of Mines, Energy and Water Resources, Addis Ababa. https://esdac.jrc.ec.europa.eu/images/Eudasm/Africa/images/maps/download/afr_etgm.jpg

Kazmin, V., Garland, C. R., Aklilu, A., Amenti, A., Beyth, M, Dow, D. B., et al. (1978). Geological Map of Adigrat Area, Sheet ND $37-7$. Ministry of Mines, Geological Survey of Ethiopia, Addis Ababa

Kazmin, V., Seife, M. B., Nicoletti, M., \& Petrucciani, C. (1980). Evolution of the northern part of the Ethiopian rift. Accad. Naz. Lincei, Rome 47, 275-291.

Keep, M., \& McClay, K. R. (1997). Analogue modelling of multiphase rift systems. Tectonophysics, 273(3-4), 239-270. https://doi.org/ 10.1016/S0040-1951(96)00272-7

Keir, D., Ebinger, C. J., Stuart, G. W., Daly, E., \& Ayele, A. (2006). Strain accommodation by magmatism and faulting as rifting proceeds to breakup: Seismicity of the northern Ethiopian rift. Journal of Geophysical Research, 111, B05314. https://doi.org/ 10.1029/2005JB003748

Keir, D., Hamling, I. J., Ayele, A., Calais, E., Ebinger, C., Wright, T. J., et al. (2009). Evidence for focused magmatic accretion at segment centers from lateral dike injections captured beneath the Red Sea rift in Afar. Geology, 37, 59-62. https://doi.org/10.1130/ G25147A.1

Kidane, T. (2015). Strong clockwise block rotation of the Ali-Sabieh/Aïsha Block: evidence for opening of the Afar Depression by a 'saloondoor' mechanism. In T. J. Wright, et al. (Eds.). Magmatic Rifting and Active Volcanism, Geological Society, London, Special Publications (Vol. 420, 209-219). http://doi.org/10.1144/SP420.10

Kirschner, J. P., Kominz, M. A., \& Mwakanyamale, K. E. (2010). Quantifying extension of passive margins: Implications for sea level change. Tectonics, 29, TC4006. https://doi.org/10.1029/2009TC002557

Kogan, L., Fisseha, S., Bendick, R., Reilinger, R., McClusky, S., King, R., \& Solomon, T. (2012). Lithospheric strength and strain localization in continental extension from observations of the East African Rift. Journal of Geophysical Research, 117, B03402. https://doi.org/ $10.1029 / 2011 \mathrm{JB} 008516$

La Rosa, A., Pagli, C., Keir, D., Sani, F., Corti, G., Wang, H., \& Possee, D. (2019). Observing Oblique Slip During Rift Linkage in Northern Afar. Geophysical Research Letters, 46, 10,782-10,790. https://doi.org/10.1029/2019GL084801

Le Gall, B., Leleu, S., Pik, R., Jourdan, F., Chazot, G., Ayalew, D., et al. (2018). The red beds series in the Erta Ale segment, North Afar. Evidence for a 6 Ma-old post-rift basin prior to continental rupturing. Tectonophysics, 747-748, 373-389. https://doi.org/10.1016/j. tecto.2018.10.002 
Leroy, S., D'Acremont, E., Tiberi, C., Basuyau, C., Autin, J., Lucazeau, F., \& Sloan, H. (2010). Recent off-axis volcanism in the eastern Gulf of Aden: Implications for plume-ridge interaction. Earth and Planetary Science Letters, 293, 140-153. https://doi.org/10.1016/j. epsl.2010.02.036

Leroy, S., Razin, P., Autin, J., Bache, F., D'Acremont, E., Watremez, L., et al. (2012). From rifting to oceanic spreading in the Gulf of Aden: A synthesis. Arabian Journal of Geosciences, 5, 859-901. https://doi.org/10.1007/s12517-011-0475-4

Levell, B., Argent, J., Doré, G., \& Fraser, S. (2011). Passive margins: overview. In B. A. Vining, \& S. C. Pickering (Eds.), Petroleum Geology: From mature basins to new frontiers - Proceedings of the 7th Petroleum Geology Conference (pp. 823-830). London: Geological Society. https://doi.org/10.1144/0070823

Makris, J., \& Ginzburg, A. (1987). The Afar Depression: transition: Transition between continental rifting and sea-floor spreading. Tectonophysics, 141, 199-214. https://doi.org/10.1016/0040-1951(87)90186-7

Manighetti, I., Taponnier, P., Courtillot, V., Gallet, Y., Jacques, E., \& Gillot, P.-Y. (2001). Strain transfer between disconnected, propagating rifts in Afar. Journal of Geophysical Research, 106, 13,613-13,665. https://doi.org/10.1029/2000JB900454

Manighetti, I., Tapponnier, P., Courtillot, V., Gruszow, S., \& Gillot, P.-Y. (1997). Propagation of rifting along the Arabia-Somalia plate boundary: The gulfs of Aden and Tadjoura. Journal of Geophysical Research, 102, 2681-2710. https://doi.org/10.1029/96JB01185

Manighetti, I., Tapponnier, P., Gillot, P. Y., Jacques, E., Courtillot, V., Armijo, R., et al. (1998). Propagation of rifting along the Arabia-Somalia plate boundary: Into Afar. Journal of Geophysical Research, 103, 4947-4974. https://doi.org/10.1029/97JB02758

Martin, A. K. (1984). Propagating rifts: Crustal extension during continental rifting. Tectonics, 3, 611-617. https://doi.org/10.1029/ TC003i006p00611

McClusky, S., Reilinger, R., Ogubazghi, G., Amleson, A., Healeb, B., Vernant, P., et al. (2010). Kinematics of the southern Red Sea-Afar Triple Junction and implications for plate dynamics. Geophysical Research Letters, 37, L05301. https://doi.org/10.1029/2009GL041127

McKenzie, D. P., Davies, D., \& Molnar, P. (1970). Plate tectonics of the Red Sea and East Africa. Nature, 226, 243-248. https://doi.org/ $10.1038 / 226243 \mathrm{a} 0$

Medynski, S., Pik, R., Burnard, P., Dumont, S., Grandin, R., Williams, A., et al. (2016). Magmatic cycles pace tectonic and morphological expression of rifting (Afar depression, Ethiopia). Earth and Planetary Science Letters, 446, 77-88. https://doi.org/10.1016/j. eps1.2016.04.014

Mohr, P. (1962). The Ethiopian rift system. Bulletin of the Geophysical Observatory, Addis Ababa 5, 33-62.

Mohr, P. (1967). The Ethiopian rift system. Bulletin of the Geophysical Observatory, Addis Ababa 11. 1-65.

Mohr, P. (1983a). Ethiopian flood basalt province. Nature, 303, 577-584. https://doi.org/10.1038/303577a0

Mohr, P. (1983b). The Morton-Black hypothesis for the thinning of continental crust-Revisited in Western Afar. Tectonophysics, 94 , 509-528. https://doi.org/10.1016/0040-1951(83)90032-X

Mohr, P., \& Zanettin, B. (1988). The Ethiopian flood basalt province. In J. D. Macdougall (Ed.), Continental Flood Basalts (pp. 63-110). Dordrecht: Kluwer Academic. https://doi.org/10.1007/978-94-015-7805-9_3

Mohr, P. A. (1972). Surface structure and plate tectonics of Afar. Tectonophysics, 15, 3-9. https://doi.org/10.1016/0040-1951(72)90045-5

Molnar, N. E., Cruden, A. R., \& Betts, P. G. (2017). Interactions between propagating rotational rifts and linear rheological heterogeneities: Insights from three-dimensional laboratory experiments. Tectonics, 36, 420-443. https://doi.org/10.1002/2016TC004447

Molnar, N. E., Cruden, A. R., \& Betts, P. G. (2018). Unzipping continents and the birth of microcontinents. Geology, 46, 451-454. https:// doi.org/10.1130/G40021.1

Mondy, L. S., Patrice, F. R., Duclaux, G., \& Mores, L. (2018). The role of asthenospheric flow during rift propagation and breakup. Geology, 46, 103-106. https://doi.org/10.1130/G39674.1

Morton, W. H., \& Black, R. (1975). Crustal attenuation in Afar. In A. Pilger, \& A. Roster (Eds.), Afar Depression of Ethiopia (pp. 55-61). Stuttgart: Schweizerbart.

Muirhead, J. D., \& Katterhorn, S. A. (2018). Activation of preexisting transverse structures in an evolving magmatic rift in East Africa. Journal of Structural Geology, 106, 1-18. https://doi.org/10.1016/j.jsg.2017.11.004

Muluneh, A. A., Cuffaro, M., \& Doglioni, C. (2014). Left-lateral transtension along the Ethiopian Rift and constrains on the mantlereference plate motions. Tectonophysics, 632, 21-31. https://doi.org/10.1016/j.tecto.2014.05.036

Muluneh, A. A., Kidane, T., Rowland, J., \& Bachtadse, V. (2013). Counterclockwise block rotation linked to southward propagation and overlap of sub-aerial Red Sea Rift segments, Afar Depression: Insight from paleomagnetism. Tectonophysics, 593, 111-120. https://doi. org/10.1016/j.tecto.2013.02.030

Norcliffe, J. R., Paton, D. A., Mortimer, E. J., McCaig, A. M., Nicholls, H., Rodriguez, K., et al. (2018). Laterally Confined Volcanic Successions (LCVS); recording rift-jumps during the formation of magma-rich margins. Earth and Planetary Science Letters, 504, 53-63. https://doi.org/10.1016/j.epsl.2018.09.033

Pagli, C., Yun, S.-H., Ebinger, C., Keir, D., \& Wang, H. (2019). Strike-slip tectonics during rift linkage. Geology, 47, 31-34. https://doi.org/ 10.1130/G45345.1

Paton, D. A., Pindell, J., McDermott, K., Bellingham, P., \& Horn, B. (2017). Evolution of seaward-dipping reflectors at the onset of oceanic crust formation at volcanic passive margins: Insights from the South Atlantic. Geology, 45, 439-442. https://doi.org/ $10.1130 /$ G38706.1

Purcell, P. G. (2017). Re-imagining and re-imaging the development of the East African Rift. Petroleum Geoscience, 24, 21-40. https://doi. org/10.1144/petgeo2017-036

Redfield, T. F., Wheeler, W. H., \& Often, M. (2003). A kinematic model for the development of the Afar Depression and its paleogeographic implications. Earth and Planetary Science Letters, 216, 383-398. https://doi.org/10.1016/S0012-821X(03)00488-6

Reilinger, R., \& McClusky, S. (2011). Nubia-Arabia-Eurasia plate motions and the dynamics of Mediterranean and Middle East tectonics. Geophysical Journal International, 186, 971-979. https://doi.org/10.1111/j.1365-246X.2011.05133.x

Roberts, G. P., \& Michetti, A. M. (2004). Spatial and temporal variations in growth rates along active normal fault systems: An example from the Lazio-Abruzzo Apennines, Central Italy. Journal of Structural Geology, 26, 339-376. https://doi.org/10.1016/S0191-8141(03) 00103-2

Rooney, T. O. (2017). The Cenozoic magmatism of East-Africa: Part I-Flood basalts and pulsed magmatism. Lithos, 286-287, 264-301. https://doi.org/10.1016/j.lithos.2017.05.014

Sani, F., Ghinassi, M., Papini, M., Oms, O., \& Finotello, A. (2017). Evolution of the northern tip of Afar triangle: Inferences from the Quaternary succession of the Dandiero - Massawa area (Eritrea). Tectonophysics, 717, 339-357. https://doi.org/10.1016/j. tecto.2017.08.026

Saria, E., Calais, E., Stamps, D. S., Delvaux, D., \& Hartnady, C. J. H. (2014). Present-day kinematics of the East African rift. Journal of Geophysical Research: Solid Earth, 119, 3584-3600. https://doi.org/10.1002/2013JB010901 
Sichler, B. (1980). La biellette Danakile; un modele pour l'evolution geodynamique de l'Afar. Bulletin de la Société Géologique de France, S7-XXII, 925-932. https://doi.org/10.2113/gssgfbull.S7-XXII.6.925

Smith, J. V. (1993). Infinitesimal kinematics of rotational rifting with reference to en echelon marginal faults in the Red Sea region. Tectonophysics, 222, 227-235. https://doi.org/10.1016/0040-1951(93)90050-T

Souriot, T., \& Brun, J.-P. (1992). Faulting and block rotation in the Afar triangle, East Africa: The Danakil “crank-arm” model. Geology, 20 , 911-914. https://doi.org/10.1130/0091-7613(1992)020<0911:FABRIT>2.3.CO;2

Stab, M., Bellahsen, N., Quicelleur, X., Ayalew, D., \& Leroy, S. (2016). Modes of rifting in magma-rich settings: Tectonomagmatic evolution of Central Afar. Tectonics, 35, 2-38. https://doi.org/10.1002/2015TC003893

Straume, E. O., Gaina, C., Medvedev, S., Hochmuth, K., Gohl, K., Whittaker, J. M., et al. (2019). GlobSed: Updated Total Sediment Thickness in the World's Oceans. Geochemistry, Geophysics, Geosystems, 20, 1756-1772. https://doi.org/10.1029/2018GC008115

Szymanski, E., Stockli, D. F., Johnson, P. R., \& Hager, C. (2016). Thermochronometric evidence for diffuse extension and two-phase rifting within the central Arabian Margin of the Red Sea Rift. Tectonics, 35, 2863-2895. https://doi.org/10.1002/2016TC004336

Tadesse, N., Nedaw, D., Woldearegay, K., Gebreyohannes, T., \& Van Steenbergen, F. (2015). Groundwater management for irrigation in the Raya and Kobo valleys, northern Ethiopia. International Journal of Earth Sciences and Engineering, 8, 36-46.

Tesfaye, S., \& Ghebreab, W. (2013). Simple shear detachment fault system and marginal grabens in the southernmost Red Sea rift. Tectonophysics, 608, 1268-1279. https://doi.org/10.1016/j.tecto.2013.06.014

Tesfaye, S., Harding, D. J., \& Kusky, T. M. (2003). Early continental breakup boundary and migration of the Afar triple junction, Ethiopia GSA Bulletin, 115, 1053-1067. https://doi.org/10.1130/B25149.1

Tugend, J., Gillard, M., Manatschal, G., Nirrengarten, M., Harkin, C., Epin, M.-E., et al. (2018). Reappraisal of the magma-rich versus magma-poor rifted margin archetypes. In K.R. McClay \& J.A. Hammerstein (Eds.), Geological Society, London, Special Publications, (Vol. 476, pp. 23-47). https://doi.org/10.1144/SP476.9

van der Pluijm, B. A., \& Marshak, S. (2004). Earth Structure, (2nd ed.). New York: W.W. Norton \& Company Ltd.

Varet, J. (2018). Geology of Afar (East Africa). New York: Springer International Publishing AG. https://doi.org/10.1007/978-3-319-60865-5

Vink, G. E. (1982). Continental rifting and the implications for plate tectonic reconstructions. Journal of Geophysical Research, 87, 10,667-10,688. https://doi.org/10.1029/JB087iB13p10677

Williams, F. M. (2016). Understanding Ethiopia. New York: Springer International Publishing. https://doi.org/10.1007/978-3-319-02180-5

Wolfenden, E., Ebinger, C., Yirgu, G., Deino, A., \& Ayalew, D. (2004). Evolution of the northern Main Ethiopian rift: birth of a triple junction. Earth and Planetary Science Letters, 224, 213-228. https://doi.org/10.1016/j.epsl.2004.04.022

Wolfenden, E., Ebinger, C., Yirgu, G., Renne, P. R., \& Kelley, S. P. (2005). Evolution of a volcanic rifted margin: Southern Red Sea, Ethiopia GSA Bulletin, 117, 846-864. https://doi.org/10.1130/B25516.1

Wright, T. J., Ebinger, C., Biggs, J., Ayele, A., Yirgu, G., Keir, D., \& Stork, A. (2006). Magma-maintained rift segmentation at continental rupture in the 2005 Afar dyking episode. Nature, 442(7100), 291-294. https://doi.org/10.1038/nature04978

Zanettin, B., \& Justin-Visentin, E. (1975). Tectonical and volcanological evolution of the western Afar margin (Ethiopia). In A. Pilger, \& A Roster (Eds.), Afar Depression of Ethiopia (pp. 300-309). Stuttgart: Schweizerbart.

Zou, C., Zhai, G., Zhang, G., Wang, H., Zhang, G., Li, J., et al. (2015). Formation, distribution, potential and prediction of global conventional and unconventional hydrocarbon resources. Petroleum Exploration and Development, 42, 14-28. https://doi.org/10.1016/S1876$3804(15) 60002-7$

Zwaan, F., Corti, G., Keir, D., \& Sani, F. (2020). A review of tectonic models for the rifted margin of Afar: Implications for continental break-up and passive margin formation. Journal of African Earth Sciences, 164, 103649. https://doi.org/10.1016/j.jafrearsci.2019.103649

Zwaan, F., Corti, G., Sani, F., Keir, D., Muluneh, A., Illsley-Kemp, F., Papini, M. (2020). Geological data from the Western Afar margin, East Africa. GFZ Data Services. http://doi.org/10.5880/fidgeo.2020.017

Zwaan, F., Schreurs, G., \& Rosenau, M. (2020). Rift propagation in rotational versus orthogonal extension: Insights from 4D analogue models. Journal of Structural Geology, 135, 103946. https://doi.org/10.1016/j.jsg.2019.103946 